\author{
Stephen M. Dickey
}

University of Kansas

\title{
$S$-/Z- and the Grammaticalization of Aspect in Slavic
}

\begin{abstract}
Avtor zagovarja stališče, da je v zahodnih skupini slovanskih jezikov (češčina, slovaščina, lužiščina, slovenščina) sovpad odrazov $*_{s z-}$ in $* j b z$ - $v$ eno predpono povzročil (delno) gramatikalizacijo nastale predpone $s-/ z$ - kot osnovni préverbe vide $\mathrm{v}$ sistemu glagolskega vida. V drugih slovanskih jezikih do te gramatikalizacije ni prišlo (hrvaščina, srbščina) ali pa je bila predpona po- gramatikalizirana kot edini préverbe vide (ruščina, bolgarščina, makedonščina, ukrajinščina, beloruščina). $\mathrm{V}$ enem slovanskem jeziku (poljščina) izkazujeta predponi $s-/ z$ - in $p o$ - skoraj enako produktivnost.

It is argued that the phonetic coalescence of $*_{s 6}$ - and $*_{b b}$ - into a single prefix resulted in the (partial) grammaticalization of innovative $s-/ z$ - as the primary préverbe vide of the aspectual systems in a group of western languages (Czech, Slovak, Sorbian, Slovene). The other Slavic languages either did not grammaticalize a single prefix (Croatian/Serbian) or have grammaticalized po- as their sole or primary préverbe vide (Russian, Bulgarian, Macedonian, Ukrainian, Belarusian); one Slavic language has near equal productivity of $s-z$ - and po- (Polish).
\end{abstract}

\section{Introduction}

This paper examines verbal prefixation with $s-/ z$ - in the Slavic languages, focusing primarily on West Slavic and Slovene, where this prefix has been the most productive.* A description of prefixation with $s-/ z$ - is presented, and it is shown that the languages in which $s$-/z- has the highest productivity as a perfectivizing prefix correspond largely to the languages belonging to a "western" aspectual type according to Dickey (2000). The development of $s$-/z- from a coalescence of the prefixes ${ }^{*} s b^{\prime}$ and $* j b z-$ (as well as $*_{v b z-}$ to varying extents) in these languages is discussed, and on the basis of the historical development of this prefix it is suggested that the semantic nature of $s-/ z$ - has played a significant role in the particular development of the aspect category in the languages making up the western aspectual type. Aspect in the other Slavic languages (most of South Slavic as well as East Slavic) is in contrast argued to have been shaped by other developments, notable among them productive prefixation with po-.

\section{Preliminaries}

The analysis presented here is based on the overall east-west division in Slavic aspect established in Dickey (2000) on the basis of data from Cz, Slk, Sln, Pol,

* This article was supported in part by a Fulbright-Hays Faculty Research Abroad Award received from the U.S. Department of Education, as well as a New Faculty General Research Fund Grant awarded by the University of Kansas. This support is acknowledged with gratitude. I would also like to thank Marc L. Greenberg, who provided me with comments that greatly improved the presentation of Slovene and South Slavic. Finally, I am grateful for the efforts of two anonymous reviewers that helped improve various aspects of this article. All shortcomings and inaccuracies, of course, are mine alone. 
$\mathrm{Srb} / \mathrm{Cro}$, Blg, Rus and $\mathrm{Ukr}^{1}$ concerning variations in aspectual usage in habitual contexts, the general-factual, the historical present, the impf in sequences of events, performatives and other cases of coincidence, as well as differences in the derivation of verbal nouns. The result is an overall division of Slavic into two distinct aspectual types: an eastern type (Rus, Ukr, Blr, Blg) and a western type (Cz, Slk, Sln). Pol and $\mathrm{Cro} / \mathrm{Srb}$ are transitional zones between these two groups; however, Pol tends to pattern more like the east and Cro/Srb more like the west. On the basis of the observed differences, Dickey (2000) constructs a theory of the meanings of the pf and impf aspects in each group (for convenience referred to here as the east-west aspect theory), according to which the meaning of the pf aspect in the western group is TOTALITY, whereas the meaning of the pf in the eastern group is a concept labeled TEMPORAL DEFINITENESS. Totality, which is familiar from the aspectological literature (e.g., Comrie 1976), refers to the construal of a situation as an indivisible whole in time, including its beginning, middle and end; the obligatory focus on the endpoint of the situation is ordinarily due to the spatial(-temporal) profile $^{2}$ of the prefix of a perfective verb, which includes a limiting endpoint as a landmark. In a temporal sense, the endpoint marks the transition to a new state of affairs, and this is why pf verbs are so closely associated with the transition from an initial state to a new state (i.e., the TRANSITION FROM $S^{1}$ TO $S^{2}$; see the discussion of Shull's 2003 theory of prefixation below). Temporal definiteness is a different kind of concept and requires some explanation. A situation is temporally definite if it is unique in the temporal fact structure of a discourse, i.e., if it is viewed as both (a) a complete whole and (b) qualitatively different from prior and/or subsequent states of affairs. This notion has theoretical motivations which need not concern us here (for details, see Leinonen 1982 and Dickey 2000, and for a more recent analysis of Rus aspect which is very compatible with this approach, cf. Zel'dovič 2002); of primary relevance for the present discussion is the fact that temporal definiteness has as a practical effect the limitation of pf verbs in the eastern languages to contexts of (explicit or implicit) sequentiality. Following Barentsen's (1995) version of this model, we may capture the profile of sequentiality of the Rus pf nicely by schematizing the relationship of the predicate to the prior and subsequent states of affairs as $\mathrm{X} \rightarrow \mathrm{S} \rightarrow \mathrm{Y}$, where $\mathrm{S}$ is the predicate expressed by a pf verb, $\mathrm{X}$ is some other prior state of affairs, and $\mathrm{Y}$ is some other subsequent state of affairs. This schema is in fact one way of representing the location of a situation $\mathrm{S}$ in time relative to intervals characterized by its absence, i.e., $-\mathrm{S} \rightarrow \mathrm{S} \rightarrow-\mathrm{S}$ (this will become relevant in section 5).

Space considerations preclude a detailed explanation of how the hypothesized meanings for the $\mathrm{pf}$ aspect in the respective groups motivate the differing aspectual usage in the parameters considered by Dickey (2000). As an illustration, let us briefly consider two of them, taking Rus and $\mathrm{Cz}$ as representative of the eastern and western languages (respectively). The first parameter is habituality: as shown in (1),

\footnotetext{
${ }^{1}$ The following abbreviations are used in this article: Blr (Belarusian), Blg (Bulgarian), Cro (Croatian), Cz (Czech), Mac (Macedonian), OCS (Old Church Slavic), OCz (Old Czech), OPol (Old Polish), OUkr (Old Ukrainian), Pol (Polish), ORus (Old Russian), Rus (Russian), Slk (Slovak), Sln (Slovene), Sor (Sorbian), Ukr (Ukrainian), impf (imperfective), pf (perfective).

${ }^{2}$ The term profile is used here in the sense of the work of Ronald Langacker (e.g., 1987), i.e., the particular elements of a base structure that are designated by a particular linguistic unit.
} 
the eastern languages strongly prefer the impf in habitual utterances, whereas the pf is quite common in the western languages.

(1) a. Každyj den' on *vyp'et ${ }^{p} /$ vypivaet $^{i}$ po odnoj rjumke vodki.

'He drinks a glass of vodka every day.'

b. Vypije ${ }^{p}$ jednu skleničku vodky denně.

The analysis is fairly simple: in the west, a habitual situation viewed on the basis of a single representative instance event can be coded pf if that situation is viewed in its totality (as a complete whole); in (1) the quantification of the object facilitates the total view of the situation. Thus, what the western pf expresses in (1) is merely the action producing the transition from a full glass to an empty glass. In contrast, the temporal definiteness of the Rus pf renders it unacceptable in cases of habituality, because a habitually repeated situation cannot be viewed as uniquely locatable in time; nor is there any sequentiality present on the level of the single representative instance, i.e., (1a) contains no reference to any $\mathrm{X}$ and/or $\mathrm{Y}$ in the schema $\mathrm{X} \rightarrow \mathrm{S} \rightarrow$ $\mathrm{Y}$. This analysis is supported by the fact that the $\mathrm{pf}$ in all the eastern languages is generally acceptable in the expression of habitual sequences of events:

(2) On vsegda tak-vyp'et ${ }^{p}$ kofe i pojdet ${ }^{p}$ na rabotu.

'He's always like that-drinks his coffee and goes to work.'

[Rus]

In (2), the drinking situation is presented as the first of two sequential situations on the level of the representative instance. This fulfills the uniqueness condition (b), and the pf is acceptable.

Another illustrative parameter involves the impf general-factual. Although the impf aspect occurs in the general-factual function in all Slavic languages, differences do exist: one is that in the western languages, the impf is unacceptable in the denotation of a single achievement in the past; in the eastern languages, however, it is acceptable. Compare the examples in (3):

(3) a. Našel ${ }^{p / *}$ Nacházel $^{i}$ jsem včera tu knihu, kde je ted'?

'I found that book yesterday, where is it now?'

b. Ja naxodil ${ }^{i}$ ètu knigu včera, gde ona? ${ }^{3}$

[Rus]

In the west, the meaning of totality expressed by the pf renders it acceptable in the denotation of a single achievement, which is necessarily a totality, regardless of the overall context. As for Rus, the general-factual function is inherently incompatible with the temporal definiteness of the pf aspect, as the situation in question cannot be viewed as unique in the fact structure of the discourse; note also the lack of any explicit sequentiality to motivate the pf in (3b).

Let us now turn to the impf aspect. According to the east-west aspect theory, the impf in each group has its own distinct (positive) meaning. In the west, the impf expresses QUANTITATIVE TEMPORAL INDEFINITENESS: the assignability of a situation to more than one conceptual point in time in the fact structure of a dis-

${ }^{3}$ This Rus example is taken from Štyreva (1992: 176), where it is given with its Slk equival- 
course. In (3a), this meaning contradicts the context of a single achievement, which must be assigned to a single (conceptual) point in time, with the result that the impf is unacceptable in Cz. The meaning of the eastern impf is QUALITATIVE TEMPORAL INDEFINITENESS: the non-assignment of a situation to a single, $\mathrm{u}-$ nique point in time relative to other states of affairs. Habitual events obviously cannot be located at a single, unique point in time and are thus qualitatively temporally indefinite, hence the acceptability of the eastern impf in (1) above. General-factual contexts such as (3b), in which a single achievement is not uniquely located relative to other states of affairs, also sanction the qualitative temporal indefiniteness of the eastern impf. (This brief description gives only a broad outline of the analysis; for details, see Dickey 2000.)

The east-west aspect theory as presented by Dickey (2000) primarily concerns aspect usage, as opposed to the morphology of aspect. However, certain differences between the eastern and western groups are evident in the morphology of aspect and the derivation of various kinds of Aktionsart verbs, very few of which have been discussed in detail. Dickey (2000: chapter 7) does discuss the presence of a class of specifically ingressive verbs prefixed in $z a$ - in the languages of the eastern group (as opposed the languages of the western group, where $z a$-is simply a totalizing prefix). Dickey (2001b) examines east-west differences in the scope and function of the reflexes of *-nQ-, and Dickey and Hutcheson (2003) discuss east-west differences in the derivation and function of delimitatives in po-. The analysis presented here attempts to interpret the productivity (or lack thereof) and function of the innovative prefix $s-z$ - in the Slavic languages in terms of the east-west aspect theory.

Before beginning the discussion, however, it is necessary to lay out a basic theoretical approach to aspectual prefixation in Slavic languages. As a grammatical process, aspectual prefixation itself (as opposed to Aktionsart prefixation) is rarely discussed in detail as a system, perhaps due to the array of prefixes that perfectivize verbs in any given Slavic language. The approach taken here is based on that developed by Shull (2003), who discusses the relationship between the spatial meaning(s) of a prefix and its telic and perfectivizing functions. She draws a clear distinction between the spatial and abstract uses of prefixes, and argues against the view that abstract prefixation is based on directly metaphorical mappings of the spatial meanings of prefixes to abstract domains. Shull (184-5) also suggests that all prefixes, whether involving a landmark that is a SOURCE, a PATH or a GOAL, and regardless of their particular trajector and landmark configurations, share an abstract profile of two states $S^{1}$ and $S^{2}$ (i.e., the initial state and the resultant state respectively), and that all prefixes tend to become goal prefixes profiling the attainment of $S^{2}$ due to the "goal orientation of language," which "effectively neutralizes the distinction between Source, Path and Goal prefixes when they are used abstractly" (185). Thus, all prefixes share as an abstract schema the TRANSITION FROM $S^{1}$ TO $S^{2}$, i.e., the transition from an initial state to some different resulting state. Shull (225) suggests that the spatial prototypes of prefixes are in fact subcases of the abstract SOURCE/PATH/GOAL schema and that the former "possess a richer structure and thus occupy a privileged position in the semantic network of individual prefixes". (Her analysis of Slavic prefixation is very much in the spirit of Langacker (1988), who argues that speakers derive abstract schemas from lower level, more highly spe- 
cified meanings (one of which may be a prototype), so that in addition to a prototype, speakers may also access a highly abstract schema from all nodes of the semantic network of a linguistic unit.) Shull's approach to abstract (i.e., telicizing, perfectivizing) prefixation is important for the discussion of $s-/ z$ - presented below because it emphasizes the elements of meaning that are shared by otherwise spatially disparate prefixes, which in turn can help us to understand the semantic development of $s-/ z$ - from two distinct prefixes ${ }^{*} s b^{-}$and $* j b z-$. Shull's analysis presents a number of other interesting findings which shall not be elaborated here, but will be mentioned as they become relevant in the discussion.

\section{A Description of $s-/ z$ - in Slavic}

This section presents a brief description of the prefix $s-/ z^{-}{ }^{4}$ in the West Slavic languages and Slovene. Section 2.1 discusses $*_{S b-}$ and $*_{j b z-}$ in OCS and the coalescence of the two prefixes with the advent of the fall of the jers. Section 2.2 discusses the resulting situation in West Slavic and Slovene; the productivity of $s-/ z$ - or lack thereof in the East Slavic languages and the remaining South Slavic languages is discussed in section 2.3.

The productivity of $s-/ z$ - as a perfectivizer in the West Slavic languages is well known in the aspectological literature. Yet this prefix is problematic, as it is generally recognized as having two sources: $*_{s} b^{-}$and $* j b z-$. The original source of its voiceless allomorph $s$ - was the prefix $*_{s b \text { - }}$ Its voiced allomorph $z$-developed from the erosion of Common Slavic *jbz- during and after jer-fall (i.e., in principle $* j b z_{-} \rightarrow$ $\left.* j z_{-}^{-5} \rightarrow z-\right)$. Thus, Cz, Slk, Sor ${ }^{6}$, and Pol have no prefix $i z-$ comparable to the South Slavic languages, only $z$ - (cf. Seliščev 1941/1969: 91, 234, 3177).

The same basic coalescence of $*_{s} b$ - and $* j b z$ - into $s$ - $/ z$ - has taken place in all these languages, but the details differ from language to language according to the degree of regressive voicing assimilation that has taken place (and orthographic tradition). Though $\mathrm{Cz}$, the language that has utilized $s-/ z$ - to the highest degree, has apparently established voiced $z$ - as the default (cf., e.g., zosnovat ${ }^{p 8}$ 'endow'), its orthography has made a half-hearted attempt to maintain $s(e)$ - and $z(e)$ - as separate prefixes. Nevertheless, Janka (1997: 102) points out that both sběhnout ${ }^{p}\left(\leftarrow *_{s^{\prime} b^{-}}\right)$'run down' and zběhnout ${ }^{p}(\leftarrow * j b z-)$ 'flee' are pronounced [z-], whereas both skopat ${ }^{p}(\leftarrow$ $*_{s b-)}$ 'dig away' and $z_{k o p a t}{ }^{p}(\leftarrow * j b z-)$ 'dig up' are pronounced [s-], and remarks that in $\mathrm{Cz}$ "tendencies toward the unification of $s(e)$ - and $z(e)$ - have been (and are) at work." Moreover, the effort to maintain the distinction between etymological $*_{S b}$ and $* j b z$ - has resulted in a certain amount of confusion in dictionary treatments

4 The reflexes of $*_{s \sigma_{-}}$and $* j b z$ - shall be collectively referred to as $s$-/z-, regardless of the details of voicing in the individual Slavic languages (and whether or not individual scholars group them together); where such details become relevant, the language-specific forms are referred to.

${ }^{5}$ The intermediate stage $j z-$ is attested in OCz.

${ }^{6}$ Sorbian data included in this analysis are taken from Upper Sorbian.

${ }^{7}$ Seliščev in fact only mentions the corresponding prepositions, but the developments are identical.

${ }^{8}$ An anonymous reviewer points out that "in formal speech, especially in Bohemia, the prefix $z$ - followed by a vowel is often devoiced with a glottal stop dividing the prefix and the following vowel." 
(cf., e.g., the competing spellings skazit ${ }^{p}$ and $z k a z i t^{p}$, both 'spoil'). Janka's remark seems in my view to be quite an understatement, in light of Trávníček's (1923: 175, 183-5) observations on how artificial the modern $\mathrm{Cz}$ orthographic distinction between $s$ - and $z$ - is. As Poldauf (1954: 64, fn. 4) points out, dialectal differences play a role as well: central Bohemia prefers $s(e)$-, e.g., sešit $t^{p}$ 'sew' (except in bookish words such as zemdlit ${ }^{p}$ 'become exhausted'), whereas Moravia prefers $z(e)$-, e.g., $z_{e s ̌ i t}{ }^{p}$ 'sew'. Thus, we are justified in concluding that spoken $\mathrm{Cz}$ has merged $*_{\mathrm{s}}$ and $* j b z$ - into a single prefix, with different defaults depending on the dialect, and with various artificial exceptions stemming from prescriptive efforts in dictionaries.

In Pol the default (unmarked) allomorph of the prefix has become $z(e)$-, which occurs not only before voiced obstruents but also before $s, s z$, resonants and vowels, cf., e.g., zgrupować ${ }^{p}$ 'group together', zszyćp 'sew together', zmówićp się 'agree', $z e b r a c^{p}$ 'collect' $\left(\leftarrow{ }^{*} s b-\right)$, and $s$ - occurs only before voiceless obstruents, e.g., skleic ${ }^{p}$ 'paste together' $\left(\leftarrow *_{s^{\prime} b^{-}}\right){ }^{9}$ Likewise, in Sor, Slk and Sln the unmarked allomorph is voiced. In Sor it is $z(e)$-, cf., e.g., zeńc $c^{p}$ so 'come together' and zmjasćp 'crumple' together $\left(\leftarrow{ }^{*} s b^{-}\right)$, whereas $s$ - occurs before voiceless obstruents, e.g., styknyćp "put together' $\left(\leftarrow{ }^{*} s^{-} b^{-}\right)$. In Slk, the default is $z(o)$-, cf. e.g., zobrat ${ }^{p}$ 'collect, assemble' $(\leftarrow$ ${ }^{*} s^{-} b^{-}$, zmetat ${ }^{p}$ 'sweep together' $\left(\leftarrow *_{s b^{-}}\right)$and splynút ${ }^{p}$ 'flow together' $\left(\leftarrow{ }^{*} s^{-} b^{-}\right)$.

Though the coalescence of $*_{s} b^{-}$and $* j b z$ - into $s-/ z$ - is generally treated as a West Slavic phenomenon, it must be pointed out that this same development took place in the westernmost South Slavic language, Slovene, cf., e.g., Bajec (1959: 112). But in contrast to the West Slavic languages, standard Sln has also kept the prefix $i z_{-}$, so that it disposes of both $i z_{-}$and $z^{-}(\leftarrow * j b z-)$. In Sln, many verbs would indicate an unmarked allomorph of $z$ - cf., e.g., zediniti ${ }^{p}$ 'unite' and zožiti ${ }^{p}$ 'make narrow', where $z$ - is in prevocalic position. However, as in $\mathrm{Cz}$, if the jer in $*_{s} b^{-}$produced a modern fill vowel, se- is common, e.g., segniti ${ }^{p}$ 'rot'. Note also that $s$ - is common in verbs containing reflexes of $*_{s} b n$ - retaining the nasal, either in the old centripetal meaning of the prefix (e.g., sniti ${ }^{p}$ se 'come together'), or in its resultative meaning (e.g., snesti $i^{p}$ 'eat up'). However, verbs with the more recent perfectivizing $s$ - $/ z$ - (see below) show $z$ - as the unmarked allomorph before vowels and resonants, cf., e.g., zindustrializirati ${ }^{p}$ 'industrialize' and zromantizirati ${ }^{p}$ 'romanticize'. (One might be tempted to see $z$ - before vowels and resonants not as the voiced allomorph of $s-/ z-$, but as a reduced form of $i z-$, as the $S S K J$ gives doublet forms of some recent loans, e.g., znivelirati ${ }^{p}-$ iznivelirati $^{p}$ 'level'. But many such recent loans prefixed with $z$ - have no doublet in $i z-$, e.g., zindustrializirat $i^{p}$ 'industrialize'. Note also that the press tends to prefer forms in $z-$, as does the colloquial language. In view of these facts, I consider recent loans in $z$ - to be evidence of the productivity of an innovative-though not really new-perfectivizing suffix $s-/ z-$.) Otherwise, the allomorphs of $s$-/z- occur strictly according to voicing, cf., e.g., spiti ${ }^{p}$ drink $\left(\leftarrow i z p i t i^{p}\right)$ and zbrati $^{p}$ 'collect together' $\left(\leftarrow *^{*} s_{b}-\right)$.

Thus, the distribution of voiced $z$ - and voiceless $s$ - in $\mathrm{Cz}$, Slk, Sor, Pol, and Sln often does not follow the etymological sources at all (cf. in this regard also Seliščev

\footnotetext{
${ }^{9} \mathrm{~A}$ palatalized allomorph ś- appears before $c$, e.g., ściagnaćp 'pull together'. Note also that according to Śmiech (1968: 266), Pol attests similar dialectal differences regarding the default allomorph. Voiceless $s$-, for instance, is the default in many areas of Malopolska, Silesia and southern Wielkopolska.
} 
1941/1969: 182, who makes the same point regarding the corresponding prepositions $s$ and $z$ in West Slavic). The descriptions given above show that in $\mathrm{Cz}$, Slk, Sor, Pol, and $\operatorname{Sln} *_{s} b$ - and $*_{j b z-}$ have in fact phonetically merged into a single prefix $s-/ z$-. Although $s$ - and $z$ - are distinguished in the orthography of the western Slavic languages to varying degrees, this is ultimately irrelevant to the semantic analysis presented here, which considers the consequences of the rise of $s-/ z$ - as a single prefix for the Slavic system(s) of verbal aspect.

\subsection{The Prefixes $*_{s b-}$ and $*_{j b z-}$ in OCS and the Coalescence}

In this section the hybrid nature of western Slavic $s-/ z$ - is discussed from a semantic point of view. Such an examination is, however, not a simple issue. Since diachronic developments are the focus of the analysis, the best point of departure is a review of the semantics of $*_{S b-}$ and $* j b z$ - in OCS, the oldest recorded Slavic language. The following description of OCS $s^{s} b$ - and $i z$ - is based on the information given by Słoński (1937).

According to Słoński, $s b$ - had the following meanings in OCS: (1) the CENTRIPETAL meaning (i.e., motion from many directions to a single landmark), e.g., $s b$ šiti ${ }^{p}$ 'sew together', ${ }^{\prime \prime}$ (2) the DOWNWARD-ABLATIVE meaning (i.e., motion downward from a landmark), or "generally motion from any point" (225), e.g., sbtręsti ${ }^{p}$ 'shake off'; (3) the CONCOMITANT-ACTION meaning (225), e.g., s'bpožiti ${ }^{i}$ 'live [with]'; (4) the RESULTATIVE meaning (Słoński, 5), e.g., sbzbrěti ${ }^{p}$ 'ripen'. Słoński (253) notes that the centripetal and resultative meanings are the most frequent meanings of $s^{\prime} b$, followed by the downward-ablative meaning. A count of Słoński's verb list shows that the centripetal meaning and the resultative meaning are each expressed in 47 verbs (31.5\% each); the downward-ablative meaning is represented in only 23 verbs $(15.4 \%)$, and the concomitant-action meaning is represented by only 10 verbs $(6.7 \%) .{ }^{11}$ Thus, the two primary meanings of $s b$ - in OCS were the centripetal meaning and the resultative meaning.

The latter is most important for the history of $s-/ z$ - as a perfectivizing prefix. The resultative meaning of OCS $s^{\prime} b$ - is already an abstract aspectual meaning, which even by that time had apparently become semantically detached from the concrete spatial meaning(s) of the prefix. In other words, by the time of OCS, $s^{\prime} b$ was already functioning in a manner anticipating the préverbes vides of the modern Slavic languages. Given the well documented semantic development from concrete spatial meanings via non-spatial telicity to abstract perfectivization that Slavic prefixes tend to undergo, the question that naturally arises is which of the two spatial meanings of $s b$ - served as the starting point for its resultative meaning. The situation in this regard is not entirely clear. Some verbs, such as $s b$ šiti ${ }^{p}$ 'sew together', $s^{\prime} b$ tvoriti $^{p}$ 'create' and $s^{\prime} b z b d a t{ }^{p}$ 'build' would indicate the possibility of deriving the resultative meaning from the centripetal meaning (cf. in this regard Agrell 1908:

\footnotetext{
${ }^{10}$ Regarding data from OCS and other older stages of Slavic languages, the superscripts ${ }^{p}$ and ${ }^{i}$ indicate "proto-perfective" and "proto-imperfective" respectively; it is doubtful that fully grammaticalized aspect systems existed before the fifteenth century, though the time at which it can be said that grammaticalized aspect existed probably differs among the individual Slavic languages.

${ }^{11}$ A few of Słoński's judgments are perhaps debatable, but his numbers are valuable as a reflection of the overall tendencies at work.
} 
87). In my view, an interesting piece of circumstantial evidence for this hypothesis is the fact that the OCS deadjectival/denominal inchoative verbs which according to Słoński express this resultative meaning - şmiliti $i^{p}$ se 'take pity on', sъmrbznoti ${ }^{p} s e$ 'freeze', and sbstarětti $i^{p}$ se 'age ${ }^{12}$ - manifest the very same reflexive derivational model as the very concrete centripetal sbniti $i^{p}$ se 'come together'. This is important because such inchoative predicates have no inherent predisposition towards one kind of (spatial) telicity over another: the fact that they were derived according to the reflexive centripetal model suggests that this meaning of the prefix was productively metaphorized to create resultative verbs.

On the other hand, some of Słoński’s resultative verbs can be plausibly derived from the downward-ablative meaning, e.g., sbkratiti 'shorten' (cf., German $a b$ kürzen, English cut downloff) or sbkryti ' 'hide' (cf. German abdecken 'cover'), though there are fewer such cases. Overall, it does seem that the centripetal meaning is the better candidate for the source of the abstract, resultative meaning of OCS $s b$ - We might, however, qualify this view with the observation that individual verbs could have a predilection for developing a resultative meaning from one or the other sense depending on the lexical content of the verb; thus, kratiti i 'shorten' would naturally form a pf resultative by combining with the (downward-) ablative sense of $s b^{-}$(inasmuch as shortening is effected by cutting away), whereas zbdati ${ }^{i}$ 'build' would form the same by combining with the centripetal meaning (inasmuch as building involves assembling things in one place). The notion that the lexical content of a prefix overlaps with the base meaning of a source verb to the point where the prefix becomes apparently "semantically bleached" and creates a "lexically identical" pf verb is known as subsumption, and has been a real part of the development of prefixal perfectives in Slavic (cf., e.g., Poldauf 1954 and Nübler 1990). But again, the inchoative data are convincing enough for me to assume that the centripetal meaning was the meaning most closely related to the resultative meaning of $s b$. Accordingly, we may assume that by OCS, the individual spatial meanings of $s b$-, i.e., the centripetal meaning and the downward-ablative meaning, had each produced abstract resultative meanings simply profiling the TRANSITION FROM $\mathrm{S}^{1}$ to $S^{2}$.

How conceptually distinct the resultative meaning was from the centripetal meaning is open to speculation, but this analysis does not depend on how this question is answered in any direct way. ${ }^{13}$ Again, Shull (2003) argues that abstract meanings of prefixes need not be considered to be metaphorical extensions, but rather independent meanings, as with abstract meanings there are rarely good candidates for the roles of trajector and landmark. For purposes of this discussion, I will assume

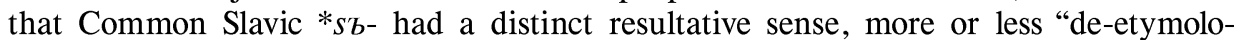
gized," and thus very likely standing in some sort of semantic network relationship with the spatial centripetal meaning (cf., in this regard, Bajec 1959: 112, who also links these two meanings). Figure 1 shows the assumed network relationships. (The network diagrams given here and below bear no claim of psychological reality, but are one way of representing the semantic structure of the prefixes in question. The nodes of the semantic network are represented by the circles, and relatively more

\footnotetext{
${ }^{12} \mathrm{Cf}$. also szszxnoti ${ }^{p}$ se 'dry up', given in the Staroslavjanskij slovar'.
}

${ }^{13}$ Note that Šlosar (1981: 91) also assumes a separate resultative meaning for $s 6-$ in OCS. 
salient nodes are represented by thicker circles. Where it is doubtful that there is any significant semantic link between two nodes, no line connects them, as in the case of the concomitant-action meaning and the resultative meaning. We may assume a general semantic link between the centripetal and downward-ablative meanings inasmuch as they both profile the TRANSITION FROM $\mathrm{S}^{1}$ TO $\mathrm{S}^{2}$.)

\section{Figure 1: Basic Semantic Network for OCS $s_{b-}$}

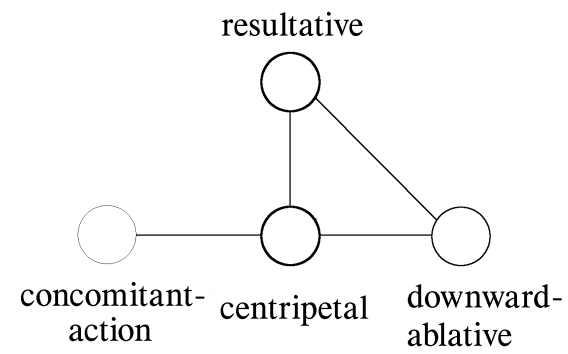

Let us now turn to OCS $i z$ - as a basis for assessing the semantics of Common Slavic *jbz-. Słoński (1937) gives three main meanings for OCS $i z-:$ (1) the ELATIVE meaning (out of), e.g., isţknoti $i^{p}$ 'pluck out'; (2) the EFFECTIVE meaning, signaling that an action is carried out 'thoroughly'14, e.g., is bxnoti ${ }^{p}$ 'dry up" ${ }^{15}$; (3) the RESULTATIVE meaning, e.g., izměniti ${ }^{p}$ 'change'; and (4) the DISTRIBUTIVE meaning, signifying that an action affects all of a set of objects/subjects one after the other, e.g., izvęzatip 'bind together [one after another]'. According to Słoński's data, equal numbers of verbs prefixed with $i z$ - have the elative and effective meanings (49 in each case, or 39\%). The resultative meaning (15 verbs) is clearly related to the effective meaning, inasmuch as thoroughness of completion is usually involved in producing a result. The distributive meaning is also closely related to the effective meaning: an action carried out thoroughly on a set of objects will affect all of them. This is why most of the verbs Słoński gives as having distributive meaning are also characterized as expressing the effective meaning; in fact, the only verb Słoński gives as simply distributive is izvęzatip. The others (a total of 9) are characterized as distributive-effective (dystrybutywno-efektywny), e.g., izbiti ${ }^{p}$ 'kill [several]', izmréti ${ }^{p}$ 'die [of several]'; the relation between the notions of thoroughness and distributivity can likewise be seen in the English kill off, die offlout. Summing up, we may conclude that the original spatial meaning of $* j b z-$, out of, produced a large number of verbs that may be broadly characterized as "resultative", for the pure resultatives $\left(\right.$ izménit $\left.^{p}\right)$, the effective verbs $\left(i s^{\prime} b x n o t i^{p}\right)$ and the distributive verbs $\left(\right.$ izvęzati $\left.^{p}\right)$ all profile the "absolute completion" (to use Jakobson's term) and accompanying result of an action. The resultative meanings of $i z$ - may be viewed as metaphorical extensions of its spatial meaning 'out of', as Bajec (1959: 112) has suggested ("what proceeds out of a verbal action is completed"), but need not be, cf. Shull's views discussed above. Figure 2 illustrates the network for OCS $i z-$ :

\footnotetext{
${ }^{14}$ Cf. Agrell (1908: 109); Agrell is the source for Słoński’s Aktionsart meanings.

${ }^{15}$ Note the same meaning with the synonymous prefix aus- in German: austrinken 'drink up', auspendeln 'swing to a standstill'.
} 


\section{Figure 2: Basic Semantic Network for OCS $i z$ -}

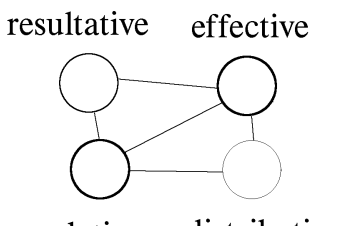

Thus, $*_{s b \text { - and }} *_{j b z}$ - both had very prominent resultative/perfective meanings in addition to their spatial meanings (from which the former were originally metaphorically derived) by the time of OCS. In this respect, they are similar, and also stand (alongside po-, which had also developed some of the same aspectual meanings by this time, cf. Słoński 1937) apart from other prefixes, whose semantic functions were more clearly dominated by their primary spatial meanings. It is indeed interesting to note that in the case of some predicates, OCS attests resultatives pre-

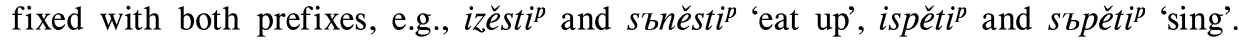
It is not my intention here to determine the precise difference in meaning between such doublets; all that is important for this discussion is that both $*_{s b-}$ and $* j b z$ could in principle produce resultative verbs from one and the same source verb. This situation is not unique to OCS, but has been observed in other Slavic languages. Witkowska-Gutkowska (1999) discusses many such pf doublets in OPol and analyzes the reasons in each case for the elimination of some in favor of one in the modern language. ${ }^{16}$ According to Witkowska-Gutkowska, the elimination of such redundant doublets involved the loss of some meanings of individual prefixes as well as the semantic specialization of various prefixes. For example, OPol attests nagotowaćp przygotować $^{p}$, ugotować $c^{p}$, and zgotowaćp ${ }^{p}$, all meaning 'prepare, ready'; of these, modern (standard) Pol has retained only przygotowaćp. While an analysis of the factors influencing the elimination of such doublets is quite interesting, equally interesting is the issue of why such doublets would appear at all, given their apparent redundancy. In my view, the cause is to be found simply in the early metaphorization of the spatial meanings of various prefixes to produce telic pf verbs. For instance, the Pol prefixes $n a-$, przy-, $u$-, and $z$ - all had spatial meanings involving trajectors and landmarks which could be metaphorized to profile the telicity of a given action (i.e., to profile merely the TRANSITION FROM $\mathrm{S}^{1}$ TO $\mathrm{S}^{2}$ ); thus, it should not come as a surprise that a certain amount of "overproduction" resulting in "redundant" doublets would take place. (This is by necessity an oversimplification of the semantic issues involved. It would be erroneous to assume an absolute degree of synonymy between nagotować ${ }^{p}$, przygotować $^{p}$, ugotować $^{p}$ and zgotowaćp: it is hard to believe that many if not all such verbs each had a particular lexical nuance added by the prefix. But the slight differences in meaning are irrelevant to the immediate concerns of this discussion. This also applies to any possible difference between OCS $i z \check{s} s i^{p}$ and $s^{\prime}$ bněsti ${ }^{p}$.) Returning to OCS $i z$ ěsti $^{p}$ and $s^{\prime}$ bněsti ${ }^{p}$, it should surprise us even less that $s b^{-}$and $i z$-, which had already developed salient resultative meanings, should produce "competing" or "redundant" doublets.

\footnotetext{
${ }^{16}$ Nefed'ev (1994: 78) briefly mentions the same process in the history of Rus.
} 
This brings us to the fall of the jers $(b, b)$, which resulted in the reduction of *jbz- to $z$ - in West Slavic, Ukr and Blr, which in turn was undoubtedly the catalyst for the coalescence of $s$ - and $z$ - into one prefix.

Šlosar (1981: 105) discounts the possibility of the replacement of $* j b z-$ by $*_{s b-}$ in Common Slavic. According to Hujer (1922/1961: 125), the final reduction of $j z^{-} \rightarrow$ $z$ - occurred in $\mathrm{Cz}$ in prehistoric times (i.e., before the fourteenth century, the time of the oldest $\mathrm{Cz}$ texts). The reduction of $* j b z-\rightarrow z-$, as well as the resulting phonetic merger of $s^{-}\left(\leftarrow *^{*} s^{-}\right)$and $z-(\leftarrow * j b z-)$, are simple to comprehend as sound changes in a system with voicing assimilation. Less clear are the consequences for the semantic meanings of the prefixes and their subsequent development.

In my view, it may be safely assumed that after the phonetic merger of $s$ - and $z$ - there was some period of time during which the spatial meanings of the prefixes were essentially unaffected, i.e., the semantic networks of the prefixes were unchanged. This is illustrated in Figure 3, which presents an (admittedly considerably simplified) "compound" semantic network for the new $s-/ z$ -

Figure 3: Compound Semantic Network for Early $s-/ z^{-18}$

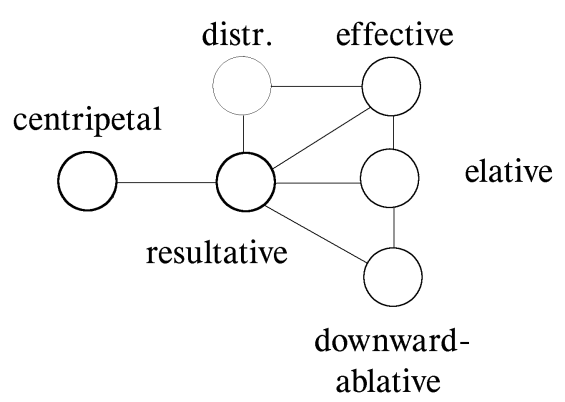

Thus, the new $z$-retained the elative meaning as one of the salient (and independent) nodes in its network. However, it is clear that this situation did not continue (and it is possible that the elative and downward ablative meanings combined into a single ablative meaning), because in West Slavic (as well as Ukr and Blr) the function of expressing the elative meaning was taken over by $v y$ - (at a relatively

Figure 4: Compound Semantic Network for $s-/ z$ - after the Spread of $v y$ -

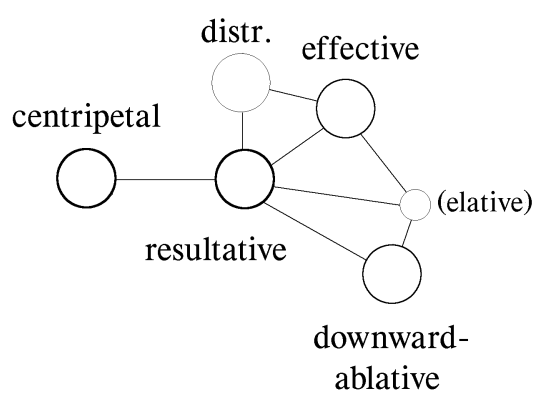

\footnotetext{
${ }^{18}$ Here the concomitant-action meaning is ignored, as it is no longer relevant to the analysis.
} 
later time in Blr and Ukr), ${ }^{19}$ cf. Šlosar (1981: 105; see section 2.2.1 for a discussion of the spread of elative $v y$ - as it relates to $s-/ z-$-). Thus, the semantic "basis" of the coalescence were the resultative meanings shared by both $s$ - and $z$-. After $v y$ - largely took over the elative meaning, the elative meaning lost its salience in the network of $s-/ z-$, and the resulting network is illustrated in figure 4.

\subsection{Innovative $s-/ z$ - in West Slavic and Slovene}

The following sections describe the coalescence and especially its semantic consequences in more detail. $\mathrm{Cz}$ is discussed in 2.2.1, and the description of $\mathrm{Cz}$ serves as the basis of the presentation. The descriptions of Slk, Sor and Sln in section 2.2.2 and the description of Pol in 2.2.3 focus primarily on the degree to which the development, scope and function of $s-z$ - in those languages resemble or differ from that of $s-/ z-$ in $\mathrm{Cz}$.

\subsubsection{Czech}

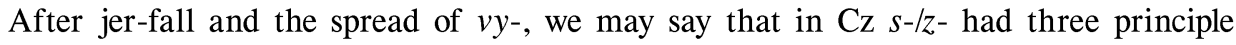
meanings, the centripetal, downward-ablative, and the cluster of resultative meanings. The resultative meanings became very productive in $\mathrm{Cz}$ (and Slk), and further development produced verbs that were not specifically resultative, but arguably expressed perfectivity without any additional semantic nuance. Šlosar (1981: 106) observes that by the end of the fifteenth century (as evidenced by the psalter of the Bible benátská, printed in 1506), "a situation closely resembling that in modern Czech had crystallized," i.e., $s-/ z$ - had developed from a primarily resultative prefix into a prefixing expressing simple perfectivity. Thus, according to Šlosar the Bible benátská attests more simple perfectives in $s$-/z- (e.g., změnitit ${ }^{p}$ 'change', ztlúcip 'beat', zstarati $^{p}$ 'grow old', ztvrdnúti ${ }^{p}$ 'harden') than effective resultatives in $s$-/z-(e.g., $z e z ̌ r a t i{ }^{p}$ 'devour', zemdléti ${ }^{p}$ 'become exhausted'). The productivity of $s-/ z$ - characteristic of the fifteenth century must be a contributing factor-in one way or another-to Vintr's (2001: 214) general view that "it is fifteenth-century Old Czech that first shows the full grammaticalization of aspect." ${ }^{20}$

Before going on, it should be pointed out that this account of the development of $\mathrm{Cz} s-/ z$ - as a single prefix differs considerably from the way $s$ - and $z$ - have been treated in the Bohemistic literature (in which different scholars have treated $s$ - and $z$ - differently). For instance, Kopečný (1962: 120-1, 126-8) treats $s$ - $\left(\leftarrow *^{*} s b-\right)$ and $z$ $(\leftarrow * j b z-)$ as completely distinct prefixes in modern Cz. This is clearly wrong. Šlosar (1981) distinguishes between $s$ - and $z$ - in $\mathrm{Cz}$, on the basis of their spatial meanings (the centripetal and downward-ablative, and elative meanings respectively). However, in his treatment of $s$ - he admits some degree of coalescence due to voicing assimilation, and suggest that the resultative meanings of $s$ - and $z$ - were "a point of contact" between the two prefixes and that "the former at some point during historical times changes into $z(e)-"(91)$. In his treatment of $z$-, he observes that "during his-

${ }^{19}$ Pol $w y$-, Sor $w u$ -

${ }^{20}$ One may agree or disagree with Vintr's opinion that aspect was "fully" grammaticalized in fifteenth-century $\mathrm{Cz}$, but it seems rather clear that by that time some state of affairs existed that fairly closely approximated the present-day aspect system in Cz. See section 5 for a discussion of the grammaticalization of aspect in $\mathrm{Cz}$. 
torical times $z$ - was reinforced in its resultative function by forms that originally had the prefix $s-"(105)$. In other words, what Šlosar is suggesting is that with the advent of $v y$ - in the expression of the elative meaning, $z$ - remained solely in its resultative meanings, and afterwards $s$ - more or less continually hemorrhaged its resultative meanings in the direction of $z$-. Yet Šlosar (104) acknowledges "sporadic" cases of $z$ - with the centripetal meaning (e.g., zběhnouti ${ }^{p}$ se "come together') and the downward-ablative meaning (e.g., zložitip 'put away/inter') which he considers to be minor tendencies in the other direction.

Though Šlosar's (1981) views are characteristically well-thought out, in my view it is useful go back to Trávníček (1923: 173-6) in an investigation of $s$ - and $z$-, i.e., $s-/ z-$, in the history of $\mathrm{Cz}$. Trávníček discusses in detail the confusion of the prepositions $s$ and $z$ as well as the corresponding prefixes $s$ - and $z-$. He notes that the prepositions $s$ and $z$ were confused only on the basis of the downward-ablative $(s)$ and elative $(z)$ meanings (both governing the genitive, i.e., $s$ with centripetal meaning was not confused with z), cf., e.g., pástip $s$ nebes, pásti ${ }^{p} z$ nebes 'fall from the heavens'. Trávníček suggests that it was the semantic proximity of the downward-ablative meaning of $s$ and the elative meaning of $z$ that facilitated the confusion of the two prepositions (in terms of Shull 2003, both are SOURCE prepositions, and their schemas differ only in the precise relationship of trajector and landmark). Moreover, Trávníček (174) points out that the alternation between $s$ nebes and $z$ nebes cannot be a consequence of a change in default voicing, as modern $\mathrm{Cz}$ distinguishes [sn-] and [zn-], cf., e.g., snést 'eat up' and znáti 'know'.

According to Trávníček (175-6), the confusion of the prefixes was more extensive: etymologically elative $z$ - alternated with etymologically downward-ablative $s$-, cf., e.g., $z p a ́ s t i{ }^{p}$ and $s p a ́ s t i{ }^{p}$ 'fall', as well as with etymologically centripetal $s-$, cf., e.g., $z v y k n u ́ t i^{p}$ and svyknúti ' 'get used to' (for numerous examples, see Trávníček 1923: 155-63). Though Trávníček does not directly speak of a coalescence of $s$ - and $z^{-}$, he does observe that "the precise differentiation between the prefixes and prepositions $s$ and $z$, which the modern $\mathrm{Cz}$ literary language has introduced into its orthography, in many cases never existed in the [OCz] language." Thus, distinctions in the current orthography bear little, if any relevance to the issue of whether etymological $s$ - and $z$-coalesced into a single prefix, and in my view there is no reason to view $s-/ z$ - in historical $\mathrm{Cz}$ as anything but a hybrid prefix with allomorphs conditioned by voicing assimilation, and thus we are justified in consistently referring to orthographic $s$ - and $z$ - together as $s-/ z$-.

The other point that Trávníček makes which is relevant for the issue of the coalescence is his view that the confusion of the prepositions $s$ and $z$ in their downward-ablative and elative meanings (respectively) reflects "a coalescence of two concepts, or meanings [i.e., the downward-ablative and the elative meanings-SMD] into one" (174). What Trávníček's remark amounts to is a suggestion that Cz semantically merged its two primary SOURCE prefixes. Considered from Shull's (2003) approach, in which downward-ablative $s$ - and elative $z$ - are to be viewed as both sharing a SOURCE trajector-landmark schema, this development seems quite plausible, especially given Šlosar's (1981: 92) observation that $s$ - expressed "motion downward or away [my italics-SMD]", i.e., $s$ - was apparently already a generic SOURCE prefix. ${ }^{21}$ Note also Trávníček's (175) observation that in modern $\mathrm{Cz}$ a phrase such as

${ }^{21}$ Circumstantial evidence for this view is Słoński’s (1937: 225) observation that already in 
ze stromu is itself ambiguous between the downward-ablative and elative meanings, and that this ambiguity is removed by the accompanying verb (e.g., slete $t^{p} z e$ stromu 'fly down from the tree' versus vyletět $t^{p} z e$ stromu 'fly out of the tree'). Thus, it is quite possible that after the fall of jers, $\mathrm{Cz}$ merged its downward-ablative and elative SOURCE prefixes into a single generic SOURCE prefix, in which case Figure 3 (and Figure 4) should have a single spatial SOURCE node in place of the downward-ablative and elative nodes.

In my view, the nature of the semantic coalescence of the spatial source meanings of $s-/ z$-is relevant for a proper understanding of the spread of $v y$ - as an elative prefix. Everything else being equal, it is difficult to figure out whether $v y$ - "displaced" $z$ - as the elative prefix in Cz (as suggested by Šlosar 1981: 107), or whether $v y$ - filled a semantic vacuum left when $z$ - lost its elative meaning. If soon after jer-fall and the coalescence of $*_{s b}$ - and $*_{j b z}-\mathrm{Cz}$ merged its two main source prefixes $s$ - and $z$-, the most reasonable assumption is that the elative meaning was taken over by $v y$ - only afterwards, as the new source prefix $s-/ z$ - was semantically underspecified. Another reason for taking this view is that $\mathrm{OCz}$ and $\mathrm{Cz}$ attest remnant verbs prefixed with $z$ - which arguably express the original elative meaning of $* j b z$ (e.g., OCz zdechnúti ${ }^{p}$ 'die', zvléci $i^{p}$ sě 'extricate oneself', $\mathrm{Cz} z$ zŕ $i^{p} i^{p}$ se 'renounce, fore-

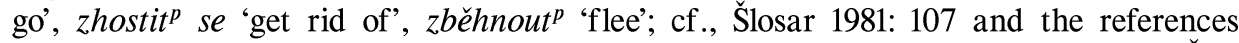
cited there); this is why $v y$ - did not entirely replace $z(e)$ - in the elative meaning (Šlosar, 107). Moreover, according to Šlosar (98-9) the productivity of elative $v y$ - has been increasing in $\mathrm{Cz}$, and abstract, metaphorical meanings have only begun to develop in historical times, which in my view indicates a relatively recent proliferation of elative $v y-.^{22}$ A final reason is that had $v y$ - replaced $* j b z$ - very early, the elative meaning of $* j b z$ - would not have been able to develop its resultative meanings in the first place.

With regard to the dynamic development of $s-z-$ as a perfectivizing prefix in $\mathrm{Cz}$, I again find Shull's (2003) analysis the most useful. After the coalescence of $*_{S b-}$ and $*_{j b z-}$, each of which had arguably already developed independent abstract resultative meanings (i.e., the TRANSITION FROM $S^{1}$ TO $S^{2}$ ), the morphological reorganization of so many resultative verbs prefixed either with $s$ - or $z$ - as being prefixed with allomorphs of the new prefix $s-/ z$ - resulted in one way or another in the establishment of a prominent semantic node of resultativity in the network of $s-z-$ These meanings of resultativity are best viewed as independent semantic meanings (or as submeanings of a single abstract meaning of change of state), and not as secondary meanings derived via metaphor (cf. Shull 2003: 184). The development of $s-/ z-$ in $\mathrm{Cz}$ as its primary préverbe vide is a quite logical (though not necessary) consequence of the disassociation of its resultative meanings from the spatial meanings that ultimately produced them.

Indicative of the role of $s-/ z$ - as a resultative prefix in $\mathrm{Cz}$ is the fact that it was the first prefix to function as a specifically distributive prefix, signaling that a situation affects all of a set of objects (or involves all of a set of subjects). Šlosar (1981:

OCS $s \sigma^{-}$expressed not just the downward-ablative meaning but also ablativity in general, "generally motion from any point".

${ }^{22}$ Kopečný (1962: 123) observes that $v y$ - in fact never functions as a perfectivizing prefix without some nuance of its lexical meaning (i.e., elativity). 
106) observes that $s$-/z- performed this function in $\mathrm{OCz}$, giving examples such as zjémati $^{p}$ 'take [all of]', zoblačiti ${ }^{p}$ 'dress [all of]', zprobijeti ${ }^{p}$ 'punch through [all of]', etc. Though Kopečný (1962: 128) gives examples of distributive verbs in $z$ - in the contemporary language, e.g., zotvírat ${ }^{p}$ 'open [all of]', the prefix is not very productive in this function (and $p o$ - has taken over as the primary distributive prefix in historical times, cf. Šlosar 1981: 120-1).

Decisive for the status of $s-/ z$ - as a préverbe vide in $\mathrm{OCz}$ was the extension of its perfectivizing role to the class of inchoative verbs, e.g., zhústnúti ${ }^{p}$ 'thicken', zeslábnúti ${ }^{p}$ 'become weak', ztvrdnútip 'harden', as this considerably diversified the predicate types that utilized $s-/ z$ - as a préverbe vide, and thus contributed to its universality as a perfectivizer. Šlosar (1981: 106) points out that in $\mathrm{OCz}, s-/ z$ - quickly became productive in the perfectivization of such inchoative verbs, and (130) makes the important suggestion that it was the (deadjectival) inchoative verbs that served as an intermediate step in the spread of $s-/ z$ - to various other kinds of verbs. As pointed out in section 2.1, inchoative predicates have no inherent predisposition towards any one kind of metaphorical telicity over another, and the fact that in $\mathrm{OCz}$ such verbs began to be prefixed with $s-/ z$ - is a strong indicator of the productivity of perfectivizing $s-/ z$ - in $\mathrm{Cz}$ from a relatively very early date. I suggest that the new productivity of $s-/ z$ - as a perfectivizer of inchoatives in $\mathrm{OCz}$ was the result of the newly created (or consolidated) node of abstract resultativity which was central to the semantic network of $s-/ z-$; I see no compelling reason at all to view the perfectivization of inchoatives with $s-/ z$ - as the result of a direct metaphorization of one of the spatial meanings of the prefix. In other words, the semantic mechanism behind the perfectivization of inchoatives in $\mathrm{OCz}$ was the new abstract meaning of $s-/ z-$ : the TRANSITION FROM $S^{1}$ TO $S^{2}$. Here it is worth pointing out that Kopečnýs (1962: 120-1, 126-8) approach of attempting to make a strict distinction between $s$ - and $z$ is misguided in that it entails that $z^{-}\left(\leftarrow * j b z^{-}\right)$became the perfectivizer of inchoative verbs in $\mathrm{Cz}$, which does not accord with the etymological evidence from any of the other Slavic languages. As pointed out in 2.1, in OCS the prefix that perfectivized inchoatives was $s^{\prime} b^{-}$, not $i z-$. Though data from contemporary Slavic languages shows that some inchoatives (mostly involving colors) have been prefixed with reflexes of *jbz-, e.g., Cro izblijedjeti ${ }^{p}$ 'fade', others have been prefixed with reflexes of $*_{s} b^{-}$, e.g., Cro zgusnuti ${ }^{p}$ 'thicken'. Even Mac, in which $i z$ - has become wildly productive as a perfectivizer, prefixes many inchoatives with $s$ - and not $i z^{-}$, as is evident from Ugrinova-Skalovska's (1960) description of Mac prefixes, cf., e.g., zbesne ${ }^{p}$ 'become furious' and snemee 'become mute'. The problem disappears if one assumes the coalescence of $*_{s b}$ - and $* j b z$ - into $s$ - $/ z$ - in Cz.

At this point it is important to mention a nuance of completeness of the change of state expressed by inchoatives in $s-/ z-$, which becomes clear when one compares such verbs with inchoatives prefixed with po- that also exist for some verbs in $\mathrm{Cz}$. The latter generally express attenuation of the result. Thus, bélet ${ }^{i}$ turn white' has as its "default" zbělet ${ }^{p}$, whereas pobělet ${ }^{p}$ means 'turn somewhat white'

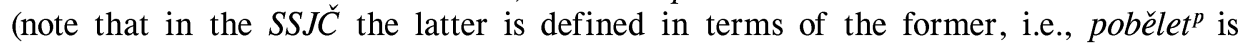
defined as trochu zbělet ${ }^{p}$ ). Other such doublets with the same difference in meaning are poblednout ${ }^{p} / z$ blednout ${ }^{p}$ 'turn pale', počernat ${ }^{p} / z \check{c ̌ e r n a t}^{p}$ 'turn black', and počervenat $^{p} / z$ červenat $^{p}$ "turn red'. The verbs in $z$ - are regularly defined as the "perfectives" of their source verbs in the $S S J \check{C}$, which gives a very good indication of their 
default status vis-à-vis their correlates prefixed with po-. Here one can see the original resultative meaning of $s-/ z-$ : in order for inchoatives prefixed with $s-/ z$ - to become established as the default perfectives in contrast to their correlates prefixed with po-, the nuance of thoroughness must have been salient. It should be mentioned that not all inchoatives prefixed in po- attested in the SSJČ are currently used with attenuative meaning; some are simply rare verbs (e.g., podétinštět $t^{p}$ as opposed to standard zdétinštět ${ }^{p}$ 'become childlike'). What is important is that $s-/ z-$ has established itself as the sole productive prefix in the perfectivization of inchoatives in $\mathrm{Cz}$.

Prefixation with $s-/ z$ - has become the main way perfectivizing a related class of $\mathrm{Cz}$ verbs, the factitives. Thus, bělit ${ }^{i}$ 'color white, whitewash' has as its pf zbělit ${ }^{p}$.

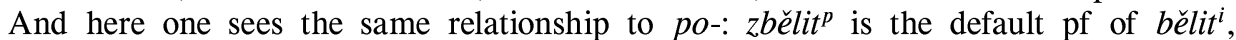
whereas the SSJČ defines pobělit ${ }^{p}$ as 'make somewhat white'. Another such doublet is pokroutit $/$ zkroutit ${ }^{p}$ 'distort'. Here as well it should be pointed out that some verbs in $p o$ - are simply archaic (e.g., pohasit ${ }^{p}$ 'extinguish') or otherwise stylistically marginal, which is again an indication of the ascent of $s-/ z$ - as a productive perfectivizer in $\mathrm{Cz}$.

Not only did $s-/ z$ - take over the perfectivizing function of its two source prefixes ${ }^{*} s^{\prime} b-$ and $* j b z-$, but it also made inroads on another old telic perfectivizing prefix, $v z-$, which again is an indication of its productivity. Hujer 1922/1961: $125 \mathrm{ob}$ serves that $v z$ - essentially became $z$ - in OCz (cf. in this regard also Gebauer 1963: 435-7). For example, 'lift up' is now $z$ dvihati/zdvihnout ${ }^{p}(\leftarrow v z-)$. Gebauer gives many other examples, suggesting that old $v z$ - was more likely to reduce to $z$ - if it was followed by one or more consonants (cf., e.g., $z d v i h n o u t^{p}$ ) than if it was followed by a vowel. An example of the retention of $v z$ - in prevocalic position is $v z i t i^{p}$ 'take', vzal 'took' [masc.]. But some of Gebauer's (435-6) examples, e.g., Modern Cz zorati $^{p}\left(\leftarrow\right.$ vzorati $\left.^{p}\right)$ 'dawn', zeptati ${ }^{p}$ se $\left(\leftarrow v_{\text {veptati }}^{p}\right.$ še $)$ 'wonder', and the $\mathrm{OCz}$ doublets wzechce $/ z e c h c z e^{p}$ 'wanted', wzebranyep/zebranijp 'chosen', etc., indicate that $v z$ became $z$ - quite readily in prevocalic position. In fact, vziti is more likely to be exceptional than zorati $^{p}$ and zeptati ${ }^{p} s e$, as its present tense adds a jer reflex to the prefix: vezmem ${ }^{p}$ 'I will take', etc. On the other hand, literary $\mathrm{Cz}$ has retained $v z$ before one or more consonants, e.g., vzhlédnout ${ }^{p}$ 'look up', vzkličit ${ }^{p}$ 'sprout up' $v z k r$ riknout ${ }^{p}$ 'shout out'. If in some cases $v z$ - became $z$ - before vowels and in other cases remained $v z$ - before consonant clusters, then we are justified in asking exactly what role phonetics played in the change from $v z$ - to $z$ - in some $\mathrm{Cz}$ verbs.

The phonetic resemblance no doubt played some role, but to reduce the change to phonetics as Gebauer does leaves us with no real motivation for the change where it did take place, ${ }^{23}$ given the inconsistency with which it occurred. In this respect it is important to point out Trávníček's (1923: 179-80) observation that zblúditi ${ }^{p}$ 'err' existed alongside $v z$ blúditi $^{p}$ before the phonetically conditioned change $v z^{-} \rightarrow z^{-}$took place and that it is incorrect to assume that verbs in $z-$, e.g., zbudit ${ }^{p}$ wake up, developed only from those prefixed in $v z-$, e.g., $v z b u d i t i^{p}$, etc. In other words, it is likely that $s$ - $/ z$ - was replacing $v z$ - at a time before the morphophonemic change $v z$ -

${ }^{23}$ Gebauer (435) observes that the standard language (obecná čeština) regularly changed $v z$ to $z$ - before consonants, which gives us something more closely resembling a morphophonemic change, but this still does not explain the cases in which $v z_{-} \rightarrow z$-before vowels. 
$\rightarrow z-.^{24}$ Thus, I think it is more likely that there were two processes that occurred, a morphophonemic change $v z_{-} \rightarrow z$ - and a spread of the new productive préverbe vide $s-/ z$ - at the expense of its older counterpart $v z$ - Note that Trávníček's (177-82) account of the alternations $s-/ z-/ v z$ - emphasizes the disappearance of slight lexical differences between verbs containing the various prefixes, as well as the fact that the status of $s-, z-$ and $v z$ - as préverbes vides was responsible for the alternations.

Thus, we are justified in concluding that, regardless of a morphophonemic change $v z^{-} \rightarrow z^{-}, s-/ z-$ began to replace $v z^{-}$as a perfectivizing prefix in $\mathrm{OCz}^{25}$ If $s-/ z$ - spread at the expense of $v z$ - in $\mathrm{OCz}$, then we must be able to semantically motivate the switch. This can be done quite easily. Here again we see the relevance of Shull's observation that SOURCE, PATH and GOAL prefixes, regardless of the configuration of trajector and landmark, share an abstract schema of the TRANSITION FROM $\mathrm{S}^{1}$ TO $\mathrm{S}^{2}$, which they profile when used abstractly. If in OCz $s-/ z$ - was already becoming established as an abstract perfectivizer, then it is possible that it would take over the perfectivization of verbs from other telic prefixes profiling the TRANSITION FROM $S^{1}$ TO $S^{2}$ on the basis of that shared semantic meaning.

Another indicator of the productivity of perfectivizing $s-/ z-$ in $\mathrm{Cz}$ is the current situation regarding the perfectivization of loan verbs. As is well known, loan verbs offer an ideal way to assess which prefixes are currently productive as perfectivizers in a given Slavic language. According to Rusínová (2001: 220), $z$ - is undoubtedly the most productive perfectivizing prefix in $\mathrm{Cz}$, cf., e.g., the following prefixed pf loan verbs: zbojkotovat ${ }^{p}$ 'boycott', zdiagnostikovat ${ }^{p}$ 'diagnose', zdigitalizovat ${ }^{p}$ 'digitalize', zformátovat $^{p}$ 'format', zmonitorovat ${ }^{p}$ 'monitor', znormalizovat $^{p}$ 'normalize', zrecidivo$v{ }^{p}$ 'have a relapse', zrelaxovat $^{p}$ 'relax', zunitarizovat ${ }^{p}$ 'make unitarian', etc. Rusínová (224) observes that perfectivizing $z$ - has little or no spatial or other concrete meanings. So the fact that $z$ - is used to perfectivize loan verbs makes sense, given the fact that many new verbs loaned into a Slavic language will provide no motivation for telicity resulting from a particular spatial configuration.

One last important indicator of the productivity of $s-/ z$ - as perfectivizer is evidence of a weak tendency to generalize $s-z$ - as a perfectivizer at the expense of other prefixes, at various times. In particular, $s-/ z$ - apparently forms a number of variant pf verbs alongside other perfectives. ${ }^{26}$ Some examples of such doublets are pofantit $^{p}$ se-zfantit ${ }^{p}$ selfantit ${ }^{i}$ se 'go crazy over', nafilmovat ${ }^{p}-z$ filmovat $^{p} /$ filmovat $^{i}$ 'film', prefiltrovat ${ }^{p}-$ zfiltrovat $^{p} /$ filtrovat $^{i}$ 'filter', vyformovat ${ }^{p}-z_{\text {formovat }}{ }^{p} /$ formovat $^{i}$ 'form', poněmčit ${ }^{p}-z$ němčit $t^{p} / n e ̌ m c ̌ i t ~ ' G e r m a n i z e '$ and umř́t ${ }^{p}-z e m r \check{r} i t^{p} / m r \check{r} i t^{i}$ 'die'. The point is nicely illustrated by the following examples containing nafackovat ${ }^{p}$ and zfackovat $^{p}$, which reported the very same crime in different newspapers:

${ }^{24}$ Trávníček (180) points out as well cases in which $v z$ - appeared alongside original $z$-, e.g., $v z k u s i t i^{p} / z k u s i t i^{p}$ 'try', and suggests that such pairs were created in analogy to the pairs where $v z$ was the original prefix. Note that in order for this to happen $v z$ - and $z$ - must have been "competing" before any morphophonemic change.

${ }^{25}$ Note also that one might consider it irrelevant whether a morphophonemic change $v z_{-}^{-} \rightarrow z_{-}^{-}$ was the mechanism for the replacement of $v z$ - by $z-$, as the end result is the same: the spread of $s-/ z$ - as a perfectivizing prefix. I would suggest that in fact both processes probably occurred in a kind of feedback loop, each encouraging the other.

${ }^{26}$ Cf., Šlosar (1981: 130). 
(4) a. Jeho partnerka v osmém měsíci těhotenství se ho zastala a Sobek ji nafackoval ${ }^{p}$.

'His spouse, who is eight months pregnant, stood up for him and Sobek slapped her.'

$[\mathrm{Cz} ;$ Dnes $]$

b. Muže surově kopal i do obličeje, ženu v osmém měsíci těhotenství, zfackoval ${ }^{p}$.

'He also kicked the husband brutally in the face; he slapped the wife, who is eight months pregnant.'

[Cz; Blesk $]$

If $s-/ z$ - is or has been competing with other prefixes to form pf verbs, the most reasonable conclusion is that such competition is the result of a tendency to generalize $s-/ z$ - as the grammatical marker of perfectivity in $\mathrm{Cz}$.

The historical development of a purely abstract perfectivizing prefix $s-/ z$ - in $\mathrm{Cz}$ is very interesting with regard to the grammaticalization of its category of aspect. Though a more detailed discussion of issues involved with grammaticalization is presented in section 5, some preliminary remarks are appropriate at this point. We may say that aspect is a grammatical category in $\mathrm{Cz}$ because the great majority of predicates are expressed in (perhaps contextually determined) pairs of verbs, and the $\mathrm{impf} / \mathrm{pf}$ aspect distinction is not restricted to a particular tense (e.g., past) or even finite forms. Though Shull's point that the schema TRANSITION FROM $S^{1}$ TO $S^{2}$ may be extracted from virtually any source or goal prefix is surely correct, in my view the grammaticalization of aspect in the individual Slavic languages will be accompanied by efforts to generalize a single prefix to varying degrees in each. In $\mathrm{Cz}$, it is clear that the prefix which has been generalized to the highest degree is $s-/ z-$. Not only is it the most productive prefix in the perfectivization of loan verbs, but it also has found the most diverse application as far as transformative predicate types are concerned: $s-/ z$ - perfectivizes ordinary transitive verbs (e.g., budovat $^{i} / z$ budovat $^{p}$ 'build', hotovit ${ }^{i} / z$ hotovit ${ }^{p}$ 'produce', lomit'/zlomit ${ }^{p}$ 'break', etc.), inchoatives (e.g., zfamfrnět $^{p}$ 'go crazy', zchladnout ${ }^{p}$ 'become cold', zeslábnout ${ }^{p}$ 'weaken', etc.), and factitives (e.g., famfrnit $^{p}$ drive crazy, zchladit ${ }^{p}$ 'make cold', zeslabit ${ }^{p}$ 'make weak', etc.). According to Slosar (1981: 106-7), $s-/ z$ - is currently the "primary" perfectivizing prefix in Czech.

Inasmuch as $s-/ z$ - has played a role in the grammaticalization of aspect in $\mathrm{Cz}$, it is important to keep in mind that the initial catalyst for the development of $s-/ z$ as an abstract perfectivizing prefix was the purely accidental coalescence of $*_{s} b^{-}$ and $* j b z$ - resulting from jer-fall. Therefore, the evident steps towards the grammaticalization of aspect in $\mathrm{Cz}$ should not necessarily be viewed as a teleological process, and the post-Common Slavic grammaticalization of aspect in the individual languages is to be viewed as contingent on developments specific to individual Slavic languages or groups of them.

To sum up, the development of $s-/ z$ - as an abstract perfectivizing prefix has been important in the grammaticalization of aspect in $\mathrm{Cz}$, and has arguably played a significant role in the formation of the semantic meaning of the pf aspect in $\mathrm{Cz}$. As abstract perfectivizing $s-/ z$ - had as its origin the resultative meanings of ${ }^{*} s b$ - and * jbz- which were based on the schema TRANSITION FROM S $\mathrm{SO}^{2}$, which was in turn based on the telicity abstracted from the centripetal and elative meanings of 
$*_{s b^{-}}$and $*_{j b z^{-}}$, its pf meaning has necessarily been one that is very telic. In the following sections, the other western Slavic languages are considered, and it is shown that $s-/ z$ - has played an important role in the perfectivization of verbs in Slk, Sor, Sln (section 2.2.2) and Pol as well (section 2.2.3)

\subsubsection{Slovak, Sorbian and Slovene}

Let us start with Slovak. The situation in Slk closely resembles that of Cz. Smirnov (1970: 90, 99) observes that $s-/ z$ - is quite productive in the perfectivization of loan verbs, cf., e.g., alarmovat ${ }^{i} /$ alarmovat $^{p}$ 'alarm', duplovat ${ }^{i} / z$ duplovat ${ }^{p}$ 'double', redigovati/zredigovat ${ }^{p}$ 'direct'. Like $\mathrm{Cz}$, loan verbs tend to be biaspectual and are prefixed with $s-/ z$ - to make them unambiguously pf. Smirnov (92) also points out that $s-/ z-$ is productive in the perfectivization of inchoative verbs, cf., e.g., zbohatnút ${ }^{p}$ 'become rich', zhasnút ${ }^{p}$ 'go/die out', zintenzívniet ${ }^{p}$ 'intensify', zmlknút ${ }^{p}$ 'fall silent', etc., and that such pairs are quite numerous in Slk. Note also that factitives are prefixed with s-/z-, cf., e.g., zbožšstit 'make poor', zdražit ${ }^{p}$ 'make expensive', zhoršit ${ }^{p}$ 'make worse', zmladit $^{p}$ 'rejuvenate', etc. It is worth pointing out that in contrast to $\mathrm{Cz}$ grammarians, Horecký (1959: 200) states that $s^{-}, z^{-}$and $z o$ - are allomorphs of a single prefix in Slk (this is also the position taken by the $M S J$ : 414). Given the overall close resemblance between $\mathrm{Cz}$ and Slk with regard to $s-/ z_{-}^{-}$, this description of Slk will suffice.

Sor shows the same development as $\mathrm{Cz}$ and Slk. Though Werner (2003: 144) for some reason excludes $z^{-}$as a reflex of $* j b z_{-}$, it is hard to believe that the coalescence of $*_{s} b^{-}$and $* j b z$ - described in section 1 did not take place in Sor as well. The HEWONS (22: 1718-19) clearly gives etymological indications that the preposition $z$ out is a reflex of *jbz- (e.g., ze wsy 'from a village'; cf. also Seliščev 1941/1969), and there is accordingly no reason to assume a different origin for the prefix. Though almost no remnants of elative ${ }^{*} j b z$ - remain in Sor, $z u c^{p}$ so 'take off one's shoes' seems to be just that (cf., Cro $i z u t i^{p} s e$ ), and $z h u b i c^{p}$ 'lose' very likely contains a reflex of original $* j b z-\left(\mathrm{cf} .\right.$, OCS $i_{\text {zgoubiti }}^{p}$, Cro $i_{\text {zgubiti }}{ }^{p}$ ). Another piece of evidence for assuming that $* j b z$ - was a source for Sor $s-/ z$ - is the fact that $s-/ z$ - is the formant for the distributive Aktionsart (cf., Fasske and Michalk 1981: 120-2), e.g., spo$w_{\text {ró }} e^{\prime} c^{p}$ 'turn around [of all]', zesydaćp so 'sit down [of all]', zrozdawać ${ }^{p}$ 'distribute [all of]', zwotpisowaćp 'copy [all of]'; recall from section 2.1 that $i z$ - was a distributive prefix in OCS (on the basis of its resultative meaning), and currently is in $\mathrm{Cro} / \mathrm{Srb}$, Mac and $\mathrm{Blg}$, and also that $* j b z$ - was the source of distributive $s-/ z-$ in $\mathrm{Cz}$, Slk and Pol (cf., Kucała 1966: 63). Nowhere in Slavic have clear reflexes of $*^{*} b^{-}$and $*_{v b z}$ - been productive in the derivation of distributives. Note that Sor never began to derive distributives with $p o$ - like the majority of the other Slavic languages. As in $\mathrm{Cz}$ and Slk, the elative spatial meaning of old *jbz- was taken over by *vy- $(\rightarrow w u-)$.

Otherwise, $s$ - $/ z$ - in Sor shows the basically the same productivity that it does in $\mathrm{Cz}$ and Slk. For example, it has been productive in the perfectivization of inchoative verbs, cf., e.g., schudnyćp 'become poor', zbohatnyć $c^{p}$ 'get rich', zblědnyćp 'become pale' and zmjerznyć 'freeze', etc. ${ }^{28}$ It also perfectivizes factitives, cf., e.g., zbarbićc ${ }^{p}$

${ }^{27}$ Smirnov labels the prefix $s-/ z-/ z o-$, including the allomorph with the jer reflex.

${ }^{28} \mathrm{~A}$ difference between Sor and $\mathrm{Cz} / \mathrm{Slk}$ is that some inchoatives are prefixed with wo-/wob$(\leftarrow o-/ o b-)$, e.g., wobhorknyćp 'become somewhat bitter', wochłódnyćp 'become cold', womłódnyćp 
'dye', zblaznićp 'make crazy', zbohacićc 'make rich', etc. The suffixal inchoative-factitive distinction seems to exist in Sor as well, cf., e.g., zblaznjec ${ }^{p}$ 'become foolish' and $z$ btaznić ${ }^{p}$ 'make a fool of someone', zhorbaće ${ }^{p}$ 'become buckled' and zhorbaćic ${ }^{p}$ 'make buckled'. Sor appears not to make a consistent distinction between a thorough and attenuated change of state expressed by $s-/ z$ - and $p o$ - respectively. One attested pair is schilic $^{p}$ 'bend' vs. pochilic ${ }^{p}$ 'bend a little', but the doublets zhoršićp $/$ pohoršićc

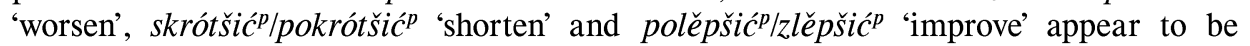
synonymous (Werner, 128, observes that for some doublets the correlate in po- occurs in figurative contexts). The surface-contact meaning of $p o^{-}$, however, produces a related distinction in meaning: pobarbic ${ }^{p}$ means 'cover a surface with paint', whereas $z$ barbic $^{p}$ expresses a more "thorough" result, i.e., 'dye'. A similar distinction exists between sčornićp 'blacken' vs. počornić ${ }^{p}$ 'blacken the surface of', and zbělićc 'color completely white' and pobělić ${ }^{p}$ 'whitewash'. Finally, s-/z- has also been productive in the perfectivization of loan verbs, e.g., skondensować ${ }^{p}$ 'condense', zbankroto$w_{a} c^{p}$ 'bankrupt', zelektrizowaćp 'electrify', zmechanizowaćp 'mechanize', which we may consider the sine qua non of its status as a préverbe vide in a given Slavic language.

Werner (144) points out that Sor $s-/ z$ - has taken over the domain of $w z-$, and that at earlier times spelling with $w z$ - was artificially recommended on an etymological basis. However, today etymological $w z$ - is $z-$, cf., e.g., zbudźićp 'wake up' for older $w z b u d z i i^{p}$. Werner does not take up the issue of how $*_{s b-}$ and $*_{v b z-\text { coalesced }}$ into Sor $s-/ z$-, i.e., whether there was a purely phonetic erosion of $w z$ - or not. This issue will not be pursued here. What is important is that as in $\mathrm{Cz}$ and $\mathrm{Slk}, s-/ z-$ took over old perfectives prefixed with $w z-$, which added to its distribution and thus salience as a préverbe vide in the Sor aspectual system.

It makes sense that $\mathrm{Cz}, \mathrm{Slk}$ and Sor all pattern very similarly regarding $s-/ z^{-}$, as they are closely related to each other genetically (non-lekhitic West Slavic languages). But as pointed out in section 1 , the rise of $s-/ z$ - as a perfectivizer is clearly evident in Sln as well (note that this fact parallels the phonological links between SIn and West Slavic discussed by Greenberg 2000: 40-1). Moreover, $s-/ z-$ has basically the same scope and functions that it does in the West Slavic languages. ${ }^{29}$ The time frame of the coalescence, or the rise of $s-/ z$ - as a perfectivizer, is not clear; the retention of $i z$ - in many sources in historical Sln obscures the picture. Merše (1995: 168) observes that verbs prefixed with $s-/ z$ - entered into aspectual pair relationships

'become fresh/young'; these correspond in $\mathrm{Cz}$ to verbs prefixed with $s$-/z- (cf., e.g., $\mathrm{Cz}$ zhorknout 'become bitter'), or to doublets in $s-/ z$ - and o- (cf., e.g., Cz ochladnout ${ }^{p} / z$ chladnout ${ }^{p}$ 'become cold'). Werner (2003: 147) notes that in Sor a few similar doublets exist, e.g., womjelknyćp/zmjelknyćp 'become silent', and points out that the correlate in wo- often expresses a figurative meaning (e.g.,

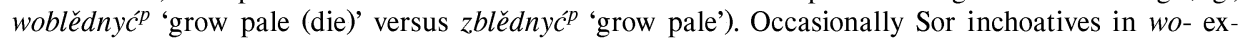
press a meaning of 'again' (cf., Werner 2003: 153), e.g., wosylnićp 'become strong (again)' vs. zesyl$n_{i c} c^{p}$ 'become strong'. Note that $o$-lob- occasionally has the same meaning in $\mathrm{Cz}$, cf., e.g., omladnout $^{p}$ 'become young (again)' vs. zmladnout $^{p}$ 'become young'. It appears that $\mathrm{Cz}$ has generalized $s-/ z-$ as a perfectivizer of inchoatives to slightly higher degree than Sor. According to Anan'eva (2003: 9), prefixation of inchoatives with $O-l o b$ - is an archaism in Pol (see section 2.2.3), and I think we may safely view prefixation of inchoatives with wo-/wob- in Sor as an archaism as well.

${ }^{29}$ The following description is drawn partly from Dickey (2003), which discusses the productivity of $s-/ z$ - in Sln. 
in the sixteenth century. ${ }^{30}$ Bajec (1959: 103) suggests that the original catalyst for the coalescence, the change $* j b z-\rightarrow z$ - resulting from jer-fall, has been continued in modern times by the Sln reduction of unstressed $-i-$, thus producing the change $i z-$ $\rightarrow z$ - This may well be true, but in my view it is important to avoid any confusion as to the older nature of the coalescence (i.e., that its origin lies in the fall of the jers). There is clear phonetic evidence in favor of this view. The Prekmurje dialects have not reduced unstressed $-i-$, yet in these dialects $* j b z$ - has nevertheless been replaced by $z^{-}$, resulting in a single prefix $s-/ z-$, which is clear from the following examples. ${ }^{31}$ zgübiti $^{p}$ 'lose' $(\leftarrow * j b z-)$, zravnàt $i^{p}$ 'even' $(\leftarrow * j b z-)$, skopàt ${ }^{p}$ 'dig up' $(\leftarrow$ $* j b z-)$, spísatip 'compose' $\left(\leftarrow *_{s b-}\right)$, zebràtip 'collect' $\left(\leftarrow *_{S b}-\right)$.

According to Bajec (1959: 112), the contemporary prefix $s-/ z$ - developed out of

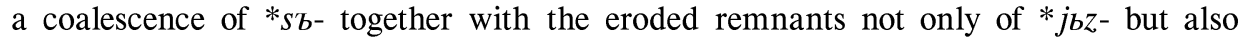
of $*^{\prime} b z-$ and $*_{r o z}$. Evidence for this process involving the latter two prefixes is the existence of doublets such as razdrobiti ${ }^{p}-z$ drobiti $^{p}$ 'crumble/break apart' and vzra$s t i^{p}-z$ rasti $^{p}$ 'grow up' in sixteenth-century Slovene, cf. Merše (1995: 167-168; 192). In my view, it is unlikely that coalescence of these prefixes in Slovene was the result of the phonetic erosion of $v z$ - and $r a z$ - as opposed to a spread of $z$ - at the expense of the other prefixes. I think this is particularly true in the case of raz-, as there is little, if any other evidence of the phonetic erosion of that prefix. Note that in $\mathrm{Cz}$ and Slk (where roz-seems to be quite stable) a few synonymous doublets in roz- and $z$ - exist as well, e.g., Cz rozdrásat ${ }^{p}-z d r a ́ s a t^{p}$ 'scrape up' (these verbs are synonymous according to the SSJC $)$. It is more likely that in these cases $s-/ z$-replaced $r a z-$ and roz- as a perfectivizer on the basis of the shared schema TRANSITION FROM S TO $\mathrm{S}^{2}$. I suggest that this process has occurred in Sln, $\mathrm{Cz}$ and Slk only in a few verbs where there was a fair amount of semantic overlap between the base verb and the prefix (e.g., 'crumbling' and the idea of 'apart') and the lexical semantic loss resulting from the elimination of $\mathrm{raz}$ - or $\mathrm{roz}$ - in favor of $\mathrm{s}-/ z$ - was minimal.

As in $\mathrm{Cz}$, Slk and Sor, Sln, $s-/ z-$ has been highly productive with loan verbs. An older example is zglihati ${ }^{p}$ 'even out'. A search of the OSSJ shows that $s-/ z$ - is the most productive prefix in the perfectivization of loan verbs, counter to Plotnikova's (1971: 35) view that $i z$ - is the most productive prefix in this function. (The OSSJ attests $105 \mathrm{pf}$ loan verbs prefixed with $s$ - $z$ - compared with only 19 prefixed with $i z-$-) Examples are individualizirati ${ }^{i / p} /$ zindividualizirati $^{p}$ 'individualize', manipulira$t_{i}^{i / p} /$ zmanipulirati $^{p}$ 'manipulate', pakirati ${ }^{i / p} /$ spakirati $^{p}$ 'pack', etc. A particular characteristic of Sln is that $s-/ z$ - often competes with $i z$ - as the perfectivizing prefix for one and the same biaspectual loan verb, producing doublets such as balancirati ${ }^{i / p} / i^{2}-$

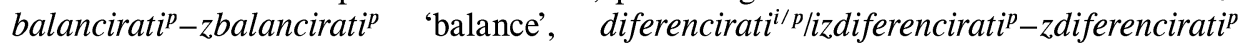
'differentiate', nivelirati ${ }^{i / p} /$ iznivelirati $^{p}-$ znivelirati $^{p}$ 'level'. When loan verbs occur with a prefix in the contemporary press, I have found them to be prefixed with $z$ - and not $i z-$, e.g., zblanširati ${ }^{p}$ 'blanch', ziritirati ${ }^{p}$ 'irritate', zmiksati ${ }^{p}$ 'mix', etc.

The same situation exists regarding native Slavic verbs. Where doublets exist for native Slavic verbs, for example, ${ }^{2} z$ piti $^{p} /$ spiti $^{p}$ 'drink [up]' $\left(\leftarrow p i t i^{i}\right.$ 'drink'), the contemporary press prefers the variant in $s-/ z-$; compare for example the following (re-

\footnotetext{
${ }^{30}$ It is worthing noting that Merše (1995) does not take the issue of aspectual pairs lightly.

${ }^{31}$ These examples were kindly provided to me from the card files of the Slovar stare knjižne prekmurščine by Dr. Majda Merše.
} 
duced) headline from the newspaper Novice:

Spil $^{p}$ kislino in si prerezal vrat.

'He drank acid and slit his throat." 32

[Sln; Novice]

The Sln informants I have spoken with are clear in their view that the (standard) colloquial language only uses the variants in $s-/ z-$. These facts indicate not only that $i z$ - as an "empty" perfectivizer is at the very least restricted to very formal registers (or perhaps an artifact of prescriptivist tendencies in Sln dictionaries), but also that $*_{s b-}$ and $* j b z-$ have in fact coalesced into $s-/ z-$. The only exception is clearly elative $i z-$, which remains in the standard language, e.g., izhajati ${ }^{i} /$ iziti $^{p}$ ' 'go out', etc.

Sln $s-/ z$ - has also been productive in the perfectivization of inchoative verbs, cf., e.g., shujšati ${ }^{p}$ 'lose weight', stemniti ${ }^{p}$ se 'darken', zboleti ${ }^{p}$ 'fall ill' and zogleneti ${ }^{p}$ 'carbonize'. However, in SIn it has nevertheless not been as productive in this role as it has in $\mathrm{Cz}$ and $\mathrm{Slk}$. Various inchoatives prefixed with $s$-/z- in $\mathrm{Cz}$ have equivalents in Sln that are prefixed with other prefixes, cf., e.g., $\mathrm{Cz}$ zesurovět ${ }^{p}$ and $\mathrm{Sln}$ posuroveti $^{p}$ 'become wild', $\mathrm{Cz}$ ztichnout ${ }^{p}$ and SIn utihniti ${ }^{p}$ 'quiet down'. Notably, many inchoative verbs that are prefixed with $s-/ z$ - in $\mathrm{Cz}$ are prefixed with $o$ - $/ o b$ - in $\mathrm{Sln}$, cf., e.g., $\mathrm{Cz}$ zestárnout ${ }^{p}$ and $\mathrm{Sln}$ ostareti $^{p}$ 'age', $\mathrm{Cz}$ zchromnout $^{p}$ and $\mathrm{Sln}$ ohrometi $^{p}$ 'become lame', $\mathrm{Cz}$ zvadnout $^{p}$ and Sln oveneti ${ }^{p}$ 'wilt', etc. Just as in the case of Sor (see fn. 28), we may consider the prefixation of inchoatives with $o-/ o b$ - to be an archaism, and therefore as an indication that $s-/ z$ - has not been used to prefix such verbs to the extent that it has in Cz. On the other hand, it seems that newer (loan) verbs that fall into the inchoative class are prefixed with $s-/ z-$, e.g., skristalizirati ${ }^{p}$ "crystallize'. Some older inchoative verbs have doublets in $s-/ z$ - and $p o-$, primarily those denoting the gaining of various colors, e.g., zbeleti ${ }^{p}-$ pobeleti $^{p}$ 'whiten', and sčrne$t i^{p}$-počrnet $i^{p}$ 'blacken', though according to informants there does not seem to be any semantic distinction between them.

The same situation holds regarding the prefixation of factitives. Some factitives in Sln are prefixed in $s-/ z-$, as in $\mathrm{Cz}$, cf., e.g., $\mathrm{Cz} z k r$ rrivit $^{p}$ and Sln skriviti ${ }^{p}$ 'bend', whereas others utilize other prefixes, notably $o$-lob- (cf., e.g., $\mathrm{Cz}$ zkrvavit ${ }^{p}$ and $\mathrm{Sln}$ okrvaviti $^{p}$ 'bloody', $\mathrm{Cz}$ zlehčit ${ }^{p}$ and $\mathrm{Sln}$ olajšati ${ }^{p}$ 'make easy') and $u$ - (cf., e.g., $\mathrm{Cz}$ zladit $^{p}$ and SIn uglasiti 'tune'). It is interesting that Sln does not have the tidy system of suffixation that $\mathrm{Cz}$ does (- $\check{e}$ - for inchoatives, $-i$ - for factitives), so that many $\mathrm{Cz}$ inchoatives in $z-\ldots-\check{e}$ - have Sln equivalents that are reflexive factitives, cf., e.g., $\mathrm{Cz}$ zbystřet ${ }^{p}$ and Sln zbistriti ${ }^{p}$ se 'become clear', $\mathrm{Cz}$ zkrvavět ${ }^{p}$ and Sln okrvaviti ${ }^{p}$ se 'become bloody'. Likewise, doublets exist for some factitive verbs, e.g., zboljša$t i^{p}-$ poboljšat $^{p}$ 'improve', zdaljšati ${ }^{p}-$ podaljšati ${ }^{p}$ 'lengthen', and zmanjšati ${ }^{p}-$ pomanjša$t i^{p}$ 'reduce', though there does not seem to be any semantic distinction between these either.

In any case, the diversity of predicate types that utilize $s-/ z$ - as a perfectivizer is noteworthy: $s-/ z$ - has not only expanded its sphere of productivity at the expense of other prefixes (iz-, raz-, and $\left.v z^{-}\right)$in the class of transitive accomplishment predi-

${ }^{32}$ A search of the files of the Besedilni korpus for the newspaper Delo confirms this impression for izpiti $^{p} /$ spiti $^{p}$ : spiti $^{p}$ yielded 17 hits, izpiti $^{p} 0$; among past-tense forms, spil ${ }^{p}$ yielded 76 hits, izpil $l^{p}$ only 8. 
cates, but has also been productive as a préverbe vide for inchoatives and factitives. Furthermore, as mentioned above, it is now the most productive prefix for the perfectivization of biaspectual loan verbs. In my view, these facts taken together indicate that Slovene has been taking steps towards grammaticalizing $s / z-$ as its perfectivizing prefix.

\subsubsection{Polish}

As shown in section 2 , the coalescence of $*_{s b-}$ and $* j b z$ - occurred in Pol as well (note that Pol treatments, e.g., Śmiech 1986, treat $s-/ z-$ as a single prefix, like the Slk and unlike the $\mathrm{Cz}$ literature). Klemensiewicz, Lehr-Spławiński and Urbańczyk (1981: 251) observe that the phonetically-conditioned alternation between $s$ - and $z$ existed in the sixteenth century. This puts the coalescence in Pol more or less at the same time as $\mathrm{Cz}$, though if, as Šlosar (1981: 106) suggests, $s-/ z$ - was already established as a préverbe vide in $\mathrm{Cz}$ by the beginning of the sixteenth century, it is possible that the development took place slightly later in Pol.

Szelesiński (1972: 226-7) discusses doublet formations involving $w z-$ and $s-/ z-$. He notes that there are a few dozen such doublets, e.g., wspuchnać ${ }^{p}-$ spuchnać $^{p}$ 'swell up'. He points out that the fact of the existence of a doublet for a given lexeme does not necessarily mean that the doublets arose due to the phonetic erosion of $w z-$; rather, some doublets arose due to prefixation of the same lexeme with both $w z-$ and $s-/ z-$. Szelesiński (227) makes no specific claims about which process was at work with individual verbs, but points out that the existing doublets in which the prefix adds a meaning of ingressivity, e.g., $w z b a c^{p} s^{2} e_{\varepsilon} z b a c^{p}$ się 'begin to fear', probably arose as the result of the phonetic reduction of $w z-$ to $z^{-}$, as the meaning involved (ingressivity) is one characteristic of $w z$ - in the various Slavic languages. On the other hand, he suggests that the doublet $w_{z b u d z i c^{p}-z b u d z i c^{p}}$ arose not due to erosion (i.e., wzbudzićp $\rightarrow$ zbudzic $c^{p}$ ), but from parallel prefixation (budzic ${ }^{p} \rightarrow$ wzbu-

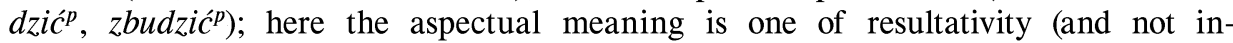
gressivity), for which according to Shull's hypothesis one can expect different telic prefixes will each profile the TRANSITION FROM $\mathrm{S}^{1}$ TO $\mathrm{S}^{2}$.

Pol $s-/ z$ - has been very productive as a perfectivizer. Agrell (1908: 85) suggests it is the primary préverbe vide in Pol. It is clear that $s-/ z$ - is the most productive prefix in the perfectivization of loan verbs: Guiraud-Weber (1998: 75) observes that $s-/ z$ - is the currently most productive prefix in the perfectivization of loan verbs in Pol, and also points out that there are many loan verbs prefixed with $s-/ z$ - are attested in various publications but which are not included in contemporary dictionaries. This again is an indication of the productivity of $s-/ z$ - as a perfectivizer in Pol. But in contrast to $\mathrm{Cz}$, Slk, Sor and $\mathrm{Sln}, s-/ z$ - does not appear to have been the most productive perfectivizing prefix in modern Pol overall. Smiech (1986: 9) lists po- as the most productive prefix. Anstatt (2003b) also suggests that po- has in fact been the most productive perfectivizing prefix in Pol. She bases her opinion on Cockiewicz (1992: 96ff.), but adds that he limits his statistics to "the most frequent Polish verbs" and that an examination of Saloni (2001) reveals that $z$ - is used to perfectiv-

\footnotetext{
${ }^{33}$ One area that shows the higher productivity of po- in Pol than in $\mathrm{Cz}$ is the relatively very productive derivation of delimitative verbs (e.g., poczytaćp 'read for a while'; cf., Dickey and Hutcheson 2003).
} 
ize loan verbs "much more frequently" than po-. Such a state of affairs is somewhat odd: one would expect that $s-/ z$ - would attain a very high degree of productivity in a language before it became productive in the perfectivization of loan verbs. In any case, it is clear that $s-/ z$ - and $p o$ - have both been quite productive in Pol. ${ }^{33}$

Another important difference between $\mathrm{Pol}$ and $\mathrm{Cz}$ (and Slk) is that in Pol s-/zhas not been quite as productive in the perfectivization of inchoative verbs, which is reminiscent of the situation in Sln. Though many $\mathrm{Cz}$ inchoatives (preliminary counts indicate about $50 \%$ ) in $s-/ z$ - have Pol equivalents in $s-/ z-$, in a considerable number of cases $\mathrm{Cz} s-/ z$ - corresponds to another prefix in Pol. The following short lists give an impression:

(6)
a. $\mathrm{Cz}$
zblednout ${ }^{p}$
zčervenat ${ }^{p}$
zdřevnatět ${ }^{p}$
zhrubnout ${ }^{p}$
ztichnout ${ }^{p}$
b. zbohatnout $^{p}$
zesmutnĕt ${ }^{p}$
zmlknout ${ }^{p}$
zobecnět ${ }^{p}$
zpustnout $^{p}$
zešilet $^{p}$

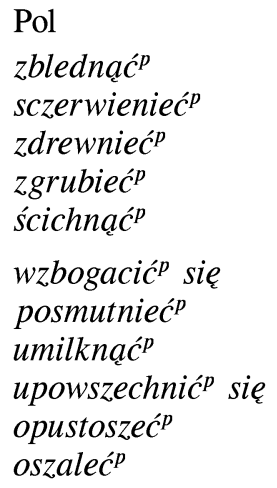

'grow pale'
'turn red'
'become woody'
'coarsen'
'become quiet'
'get rich'
'become sad'
'fall silent'
'become widespread'
'become desolate'
'go crazy'

As these few examples suggest, in addition to $s-/ z-$, Pol inchoatives tend to be prefixed with $u$-, $p o-$ and $o$-. Ananeva (2003: 9) observes that in OPol the prefix $o-/ o b(e)$ - perfectivized denominal inchoatives to a greater extent than today. Thus, the perfectivization of inchoatives in Pol with o-/ob- (as was suggested for Sor and Sln) is an archaism, and innovative prefixation with $s-/ z$ - is in fact one of the reasons for its lower frequency in contemporary Pol.

Like $\mathrm{Cz}$, Pol attests doublets inchoative doublets prefixed in $s-/ z$ - and $p o-$. Agrell (1908: 734) suggests that $s-/ z$ - expresses an absolute change and $p o-$ a relative change. Yet Anstatt's (2003b) description of Pol po- indicates that this is not entirely true; she points out that according to Piernikarski (1975: 61) Pol inchoatives in both po- and $s-/ z$ - may in principle occur with troche 'a little' and zupetnie 'completely', thus expressing either a relative or absolute change. Thus, it appears that Pol does not make the systematic distinction between attenuativity expressed by po- and completeness of change expressed by $s-z$ - that one finds in $\mathrm{Cz}$. Anstatt also observes that $p o$ - tends to have a resultative meaning with factitive verbs, so that here as well there seems to be no consistent semantic opposition between $p o$ - and $s-/ z-$.

Thus, we may conclude that, while Pol shares the development of $s-z$ - with the western languages, it departs from the western type slightly by virtue of the fact that $s-z$ - does not appear to be its clearly dominant préverbe vide, but competes in this regard with $p o-$, which has been more or less as productive as $s-/ z$ - This situation recalls not only the transitional patterning of Pol in respect of aspect usage but also its transitional status in two other areas of aspect morphology: as observed by Dickey (2000: 227) it patterns in between the eastern and western languages 
with regard to the derivation of ingressive verbs with $z a-$, and as shown by Dickey (2001b) it also patterns between the western and eastern groups with regard to the role $-n Q$ - has played in the derivation of perfective verbs. And so the transitional patterning of Pol with regard to $s-/ z$ - should not be surprising.

\section{3. $s-/ z$ - in East Slavic and the Other South Slavic Languages.}

Section 2 described a fairly compact group of western Slavic languages in which $s-/ z$ - has enjoyed very high productivity as a perfectivizing prefix: $\mathrm{Cz}, \mathrm{Slk}$, Sor, Sln. Pol also belongs to this group, though the productivity of $s-/ z$ - there is not quite as high as in the other languages. The following sections show that in the East Slavic languages and as the other South Slavic languages (Cro/Srb, Blg and Mac) $s-/ z-$ is either less productive than in the western group ( $\mathrm{Ukr}$ and Blr) or the coalescence never took place, with $i z$ - functioning as a resultative and perfectivizing prefix to varying degrees (Rus, Cro/Srb, Blg, Mac).

\subsection{East Slavic}

In $\mathrm{Ukr}$ and $\mathrm{Blr} * j b z$ - became $z$ - as in West Slavic and Sln, creating the conditions necessary for the coalescence and the creation of $s-/ z-{ }^{34}$ Rusanivs'kyj (1978) treats the development of $* j b z-$ and ${ }^{*} s b$ - in Ukr from the eleventh to the twentieth century. In Old Rusian (from the eleventh to the thirteenth centuries) $i z$ - and $s b^{-}$were still phonetically distinct and thus separate prefixes. Though minor differences surely existed, for purposes of this discussion I see no harm in assuming that $i z$ - and $s b^{-}$ in Old Rusian were essentially as they were in OCS (cf., section 2.1). In OUkr (the fourteenth-fifteenth centuries) the process of coalescence was ending, so that according to Rusanivs'kyj (250) iz-/is- was a phonetically conditioned alternate of $z$-/s- before roots beginning in a consonant, cf., e.g., sljubili ${ }^{p}$ (1433) vs. isljubujemb ${ }^{i}$ (1352) and smolvivši ${ }^{p}$ se (1404) vs. ismoviv̌ši se (1434). It is hard to interpret the overall significance of the few forms that Rusanivs'kyj gives; in my view they indicate that in the fourteenth and fifteenth centuries $i z$ - and $s$ - were still in the process of coalescing. As in the western languages $s-/ z$ - has spread at the expense of original * v'bz- in Ukr (cf. Bogdanova 1963: 301 as well as Śerex 1951, who lists "upward motion' as one of the meanings of $z-$ ), cf., e.g., zbrojity ${ }^{p}$ 'arm', zbudyty ${ }^{p}$ 'wake up', zletity $^{p}$ 'fly up'. Thus, Ukr displays the same basic coalescence of original ${ }^{*} s^{-}{ }^{-},{ }^{*} j b z_{-}$, and $*^{\prime} b z-$ that West Slavic and Sln do.

However, it seems that innovative $s-/ z$ - has played a less significant role as a perfectivizer in Ukr. This is evident from the fact that $s-/ z$ - has not become the primary perfectivizer of inchoative verbs in $\mathrm{Ukr}$. $\mathrm{Cz}$ inchoative verbs in $s-/ z$ - often have correlates in Ukr prefixed with other prefixes: cf., e.g., $\mathrm{Cz}$ zbohatnout ${ }^{p}$ vs. Ukr rozbagatity ${ }^{p}$ 'become rich', $\mathrm{Cz}$ zčervenat ${ }^{p}$ vs. Ukr. počervonity ${ }^{p}$ 'turn red', $\mathrm{Cz} z \check{c} e r-$ $n^{2}{ }^{p}$ vs. počornity ${ }^{p}$ 'turn black', zdrsnět ${ }^{p}$ vs. Ukr pošerxnuty ${ }^{p}$ 'become course', $\mathrm{Cz}$ $z_{\text {eslábnout }}^{p}$ vs. Ukr oslabnuty ${ }^{p}$ 'weaken', $\mathrm{Cz}$ zestárnout ${ }^{p}$ vs. Ukr postarity ${ }^{p}$ 'age', $\mathrm{Cz}$ $z_{\text {zě̌loutnout }}^{p}$ vs. požovtity ${ }^{p}$ 'become yellow', $\mathrm{Cz}$ zhnědnout ${ }^{p}$ vs. Ukr poburity ${ }^{p}$ 'become brown', $\mathrm{Cz}$ zmladnout ${ }^{p}$ vs. Ukr. pomolodity ${ }^{p}$ 'become young', etc. Ukr dictionaries attest some of the above inchoatives prefixed with $s-/ z^{-}$, e.g., zbahatity ${ }^{p}$ 'become rich', ž̌ervonity ${ }^{p}$ 'turn red', zmolodity ${ }^{p}$ 'become young', etc., but internet

\footnotetext{
${ }^{34}$ The same coalescence occurred with the prepositions as well, yielding $z$.
} 
searches show them each to be used much less than their correlates in other prefixes, esp. in po-. The picture is much the same for factitives, though here $s-/ z$ - seems to be even less common in Ukr: cf. $\mathrm{Cz}$ zdivočit ${ }^{p}$ vs. Ukr zrobyty ${ }^{p}$ dykym 'make wild', $\mathrm{Cz}$ zdražit ${ }^{p}$ vs. Ukr zdorožyty ${ }^{p}$ 'raise the price', Cz zeslabit ${ }^{p}$ vs. Ukr oslabyty ${ }^{p}$ 'make weak', Cz zesměšit ${ }^{p}$ vs. Ukr osmijaty 'mock', etc. A few factitives are attested in $s-/ z$ - as well as another prefix; an example is zgiršyty and pogiršyty ${ }^{p}$ 'make worse', and in this case the former is used much less frequently than the latter.

Thus, it is not surprising that in contrast to $\mathrm{Cz}$, where $s-/ z$ - had become firmly entrenched as a perfectivizer by the beginning of the fifteenth century, Rusanivs'kyj (251) observes that in the sixteenth and seventeenth centuries the frequency of $s-/ z-$ lagged behind that of several of other prefixes, namely $u{ }^{-} / v^{\prime} b^{-}, p o^{-}, p r i-, n a^{-}, z a-$, and $v y$ - (here Rusanivs'kyj is speaking of both as a lexical and aspectual prefixation). He also observes (252) that at this time the voicing assimilation of $s-/ z$ - (including $\left.z o^{-}, i z-/ i s^{-}\right)$was still an ongoing process. This suggests that Ukr completed the phonetic coalescence of $*_{s} b^{-}$and $* j b z$ - somewhat later than $\mathrm{Cz}$ and Pol (and Pol completed it no earlier than $\mathrm{Cz}$, perhaps slightly later). ${ }^{35}$

As far as perfectivizing prefixation is concerned, Rusanivs'kyj (278) observes that in the fourteenth and fifteenth centuries the most productive perfectivizing prefix was $u-/ v b^{-}$, followed by $p o-, v y$ - and only then $s-/ z-$. Rusanivs'kyj (280) also observes that during the sixteenth-eighteenth centuries po-rose to become the most productive perfectivizing prefix, followed by $u-/ v-; s-/ z-$ was only the third most productive in the role of a perfectivizer. Note again that this situation contrasts greatly with the situation in $\mathrm{Cz}$, in which $s$-/z- was very productive as a perfectivizing prefix from the fourteenth century on, whereas according to Slosar (1981: 128) the productivity of $p o$ - as a perfectivizer declined after the fifteenth century, and as a consequence, as Poldauf (1954: 64) observes, po- is not currently productive as a perfectivizing prefix in Cz. According to Rusanivs'kyj (1978: 280), it is only in the latter half of the nineteenth century that $s-z$ - becomes the most productive perfectivizing prefix, followed by $p o$ - and $z a$-. Note that there is some disagreement here, as Šerex (1951: 278) and Pugh and Press (1999: 205) consider po- to be the currently most productive Ukr prefix (followed by $s-/ z-)$; it is possible that western and eastern $\mathrm{Ukr}$ differ in this respect. If, as suggested above, ${ }^{*} s b$ - and $* j b z$-coalesced in Ukr later than in $\mathrm{Cz}$, it is possible that the lower productivity of $\mathrm{Ukr} s-/ z$ - in comparison to $\mathrm{Cz}$ is a result of the later date of the coalescence, as po-could have strengthened as a préverbe vide in the meantime.

I am not aware of any historical examination of prefixation in Blr, but according to Atraxovič and Bulaxaw (1962: 328) as well as Bulyko, et al. (1990: 199) pa- is the most productive perfectivizing prefix in Blr, followed by $s-/ z-$. This indicates more or less the same situation as in Ukr, i.e., that the productive perfectivizing pohas prevented $s-/ z$ - from clearly dominating the system of empty perfectivization, or

\footnotetext{
${ }^{35}$ Marvan (2000: 293-302) assumes the existence of a "North-Slavic Sprachbund" in which certain features were gradually transmitted by language contact from west to east, and among them includes " $z$ - as a préverbe vide". Though he does not elaborate this idea, it does seem plausible, at least in the case of $s$ - $z$-. Interestingly, the $S S M$ lists a few verbs prefixed in $z$ - that were loaned into Ukr from OPol, e.g., zvesty 'take to' $(\leftarrow$ OPol zwieść), zmerty 'die' $(\leftarrow$ OPol zemrzeć $\left.^{p}\right)$, zmyslytyp 'imagine' $\left(\leftarrow\right.$ OPol zmyślic $\left.{ }^{p}\right)$.
} 
even becoming the primary préverbe vide at all. Important in this respect is Atraxovič's and Bulaxaw's observation that Blr $p a$ - is particularly productive in the perfectivization of inchoatives, e.g., pabahacec'p 'get rich', pagrubec'p 'become coarse', paslabec'p 'become weak', etc. This situation is clearly different from the situation in $\mathrm{Cz}$, where, as has been pointed out repeatedly, $s-/ z$ - is the dominant perfectivizer of inchoatives.

As for Rus, it never underwent the coalescence of $*_{s b-}$ and $* j b z-$. Common Slavic *jbz- remained as $i z-$, which in its elative meaning has been replaced by $v y$ in historical times. However, $i z$ - has not been as marginal in Rus as is sometimes suggested, nor has it been strictly a product of South Slavic influence. Avilova (1964: 48-50) observes that $v y$ - finally replaced $i z$ - relatively late, in the nineteenth century, and that $i z$ - remained productive in the creation of certain kinds of resultatives: verbs with a nuance of intensity, e.g., izbit'p 'beat up'; verbs expressing a harmful result, e.g., izglodat'p 'gnaw'; verbs expressing the full affectedness of an object by the action, e.g., iscelovat' $p$ 'kiss all over'. On the other hand, po- has been very productive in Rus in historical times. According to Xlebnikova-Prokopovič (1956: 154), in the seventeenth century po- was among the three most productive perfectivizing prefixes in Russian, and she points out (140) that "in the language of the second half of the seventeenth century, the prefix po-also enjoyed widespread use as a purely perfectivizing prefix, occupying a significant position among the prefixes that served as simple perfectivizers." Note that Xlebnikova-Prokopovič (139) explicitly excludes delimitatives as pf partner verbs, which naturally lowers her assessment of the productivity of po- as a préverbe vide. Contemporary Rus is also characterized by high productivity of perfectivizing po-: according to Čertkova (1996: 123-24), po- is the most productive perfectivizing prefix in contemporary Russian (note that Čertkova does include delimitative $p o$ - in her assessment). Thus, although Rus did not develop $s-/ z$ - as a préverbe vide along with $\mathrm{Ukr}$ and $\mathrm{Blr}$, it does share a high productivity of perfectivizing $p o$ - with them, and we may consider productive perfectivizing $p o$ - to be one of the defining features of East Slavic. ${ }^{36}$

\subsection{Croatian/Serbian, Bulgarian and Macedonian}

In sections 2 and 2.2.2, it was shown that SIn has perfectivizing $s$-/z-like the West Slavic languages. In this respect Sln differs from the other South Slavic standard languages. However, among Cro dialects the Kajkavian dialects show the same coalescence of original $*_{s b}$ - and $* j b z-$, which is not surprising given the overall similarity and proximity of Kajkavian Cro to Sln. Peco (1991: 256) observes that a feature shared by all Kajkavian dialects is the change " $i z \rightarrow z$ ", cf., e.g., $z$ hiže 'out of the house' and zoral ${ }^{p}$ 'plowed' $[\leftarrow$ izoral]. Examples of forms that show the complete coalescence of $* s b-$ and $* j b z$ into $s$-/z- in the Bednjanski Kajkavian dialect can be found in the texts given by Jedvaj (1956; I have omitted the vocalic diacritics): zver-

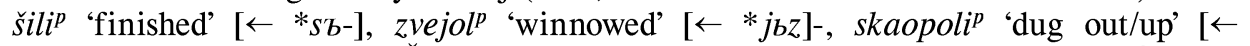
$* j b z]$-. Interestingly, a few Čakavian dialects have also merged $*_{s} b^{-}$and $* j b z-{ }^{37}$

\footnotetext{
${ }^{36}$ Thus far I have not fully addressed the function of $p o$ - to derive delimitatives with regard to its status as a préverbe vide; this issue is taken up in section 5.

${ }^{37}$ Whether the Čakavian dialects that have merged $*_{s \sigma-}$ and $*_{j b z-}$ (e.g., the dialects of Kastav, cf. Peco 1991, and Orbanići in Istria, cf. Kalsbeek 1998) all originated in the northern region of
} 
Thus, apart from Kajkavian and isolated Čakavian dialects, Cro and Srb have not merged $*_{s b} b^{-}$and $* j b z-$; they did not reduce the latter to $z$ - as a consequence of jer-fall, rather $* j b z$ - becomes $i z-$, as in Blg and Mac. Although the South Slavic languages are therefore largely irrelevant for this discussion, it is worth noting that in Cro, Srb, Blg and Mac iz- has remained a very productive resultative and perfectivizing prefix. For instance, loan verbs that are biaspectual in standard Srb and Cro readily derive pf forms prefixed with $i z-$, e.g., istrenirati ${ }^{p}$ se 'train', istuširati ${ }^{p}$ 'shower', izmanevrirati ${ }^{p}$ 'maneuver', izmanipulirati ${ }^{p}$ 'manipulate'. Indicative of the productivity of $i z$ - as a resultative perfectivizer is the fact that many are colloquial and not listed in dictionaries, e.g., Cro izlifrati $^{p} / \mathrm{Srb}$ izliferovati $^{p}$ 'deliver', izluftati $^{p}$ 'ventilate', izorganizirati $^{p}$ 'organize', etc. Note that such loan verbs prefixed with $i z$ - have strong distributive senses (akin to distributives prefixed in po-), so that they occur chiefly in contexts where all of a set of objects are to be affected, e.g., izorganizirati sve 'organize everything, ${ }^{38} \mathrm{Blg}$ and Mac also make wide use of $i z$ - in various aspectual functions (cf., e.g., Stojanov 1993: 218-9 and Ugrinova-Skalovska 1960: 659). Ivanova (133) observes that $i z$ - is statistically the most frequent "empty" prefix in Blg.

While Blg and Mac have not developed $s-/ z$ - as a préverbe vide, the situation regarding $p o$ - in these languages is more complicated than in East Slavic. Though in Blg $p o$ - is productive to some degree as a resultative prefix (cf., Stojanov 1993: 222), Ivanova $(1966: 124,133)$ suggests that po-does not function as a préverbe vide as frequently as in some other Slavic languages (e.g., Rus). For instance, po- is not as productive in the derivation of inchoatives in Blg as it is in Rus, cf., e.g., Rus

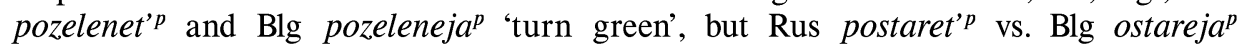
'age'. On the other hand, however, Ivanova (124) points out that Blg po- is "semantically markedly bleached" (she does not characterize any of the other Blg perfectivizing prefixes in this way), and (132) presents word counts indicating that more verbs are prefixed with po- in Blg than any other perfectivizing prefix. Though the discrepancy can be accounted for by discounting various procedural verbs (e.g., attenuatives, delimitatives, etc.), it seems that Blg po- must have primarily aspectual functions. (It is puzzling that she does not include a verb as common as popitam ${ }^{p}$ 'ask' as a case of empty perfectivization in her short list of po-perfectives.) While it seems clear that po- is not as productive in Blg as it is in East Slavic, it nevertheless occurs much more frequently as a perfectivizer than in Srb. For this reason, and also because of its productivity as a delimitative prefix (cf., Stojanov 1993: 221, and Dickey and Hutcheson 2003) I will consider Blg, to be a language which is or has been characterized by a relatively high productivity of $p o$ - as a perfectivizing prefix. As for Mac, Ugrinova-Skalovska does not specifically address the productivity of po- as a préverbe vide, but points out that "with an enormous number of verbs pofunctions simply to perfectivize them, as a resultative [prefix]" (88). Ugrinova-Skalovska (86) also observes that po- is highly productive as a delimitative prefix, to the point where "almost any verb, either simplex or derived, may be used with poin that meaning." Thus, I likewise consider Mac to be a language characterized by

Croatian linguistic territory in close proximity to Kajkavian and Slovene is an issue which cannot be investigated here.

${ }^{38}$ This is not to say that these verbs do not occur without objects quantified by sav 'all', but when they do they nevertheless have a distributive sense, so that izorganizirati ${ }^{p}$ konferenciju 'organize the conference', means in fact something like 'organize the conference from a to $z$ '. 
productive perfectivizing $p o-$.

Section 3 has shown that East and South Slavic have utilized $s-/ z$ - as a préverbe vide to a considerably lesser extent than $\mathrm{Cz}$ and the other western languages (including Sln). Though Ukr and Blr do have $s-/ z$ - as a hybrid prefix, it has not played the role in these languages that it has in $\mathrm{Cz}$ or even Pol. The remainder of South and East Slavic, i.e., Cro, Srb, Mac, Blg and Rus, has not developed $s-z-$ Ukr, Blr, Rus, Blg and Mac all share productive perfectivizing po-, though East Slavic appears to make use of it slightly more than Blg and Mac. In Srb and Cro, on the other hand, $p o$ - is not particularly productive as a perfectivizing prefix, certainly much less so than in Blg and Mac.

\section{The Distribution of $s-/ z$ - and the East-West Aspect Theory}

In the previous sections it has been shown that $s-z$ - became the primary préverbe vide in a western group of languages, i.e., $\mathrm{Cz}$, Slk, Sln and Sor ${ }^{39}$ The coalescence also took place in Pol, Blr and Ukr, but in these languages $s-/ z$ - nevertheless did not attain primary status as a préverbe vide very early, if at all, as it faced rather stiff competition from the other major Slavic perfectivizing prefix, po-. Pol may be characterized as "mixed" with regard to productive préverbes vides, since in Pol $s-/ z$ - acquired considerable productivity early on (though not to the degree of $\mathrm{Cz}$ and Slk) while po- also enjoyed considerable productivity. In Blr and Ukr the total coalescence of $s$ - and $i z$ - was apparently completed later than in the west, and in any case the competition with $p o$ - was even stiffer, so that $s-/ z$ - became the most productive préverbe vide only very late (i.e., in the latter half of the nineteenth century in Ukr), or has nevertheless remained less productive than po- (i.e., in Blr). As pointed out in section 3, Rus is also characterized by highly productive perfectivizing $p o-$.

The languages characterized by $s-z$ - as a préverbe vide are basically the same languages that belong to the western aspectual type according to Dickey (2000). Pol, while also having $s-/ z-$, is not considered by Dickey to be a member of the western group, but rather an aspectual transitional zone. As suggested in section 2.2.3, we may make sense of this in terms of the correlation with $s-/ z$ - by keeping in mind the fact that in Pol $s-/ z$ - has not been the only productive préverbe vide, but has competed in this role with po-, which has also been very productive, if not more so. The languages of the eastern group, i.e., Rus, Ukr, Blr, Blg and Mac, are distinguished by the fact that $p o$ - has been highly productive as a perfectivizer in each since the sixteenth century. This is regardless of whether they developed $s-/ z-(\mathrm{Ukr}$, $\mathrm{Blr}$ ) or not (Rus, Blg, $\mathrm{Mac}^{40}$ ).

In this respect it must be kept in mind not only that $s-/ z$ - has generally been

${ }^{39}$ Sor has either dismantled (according to Breu 2000) or transformed (according to Toops 2001) its aspect distinction in the relatively recent past. Though originally perfective prefixed verbs now exhibit patterns of usage that may be characterized as "biaspectual" with regard to typical Slavic aspect usage, I consider it beyond doubt that before the dismantling/transformation of the its aspect category Sor belonged to the western aspectual type. Therefore it is grouped in with the western languages in this discussion.

${ }^{40} \mathrm{Mac}$ is not treated by Dickey (2000), but my informal examinations of its aspect usage confirm that it displays basically an eastern pattern of usage. 
more productive in the west, but also that $p o$ - has not been more productive than $s-/ z$ - in any of the western languages. As pointed out above, $\mathrm{Cz} p o$ - is currently not productive as a perfectivizing prefix; its productivity has steadily declined since the fifteenth century. Slovak sources differ slightly: the $M S J$ (414) lists $p o$ - last among the prefixes that serve as préverbes vides, i.e., $s-/ z-/ z o^{-}, u-, n a-,-z a-, o^{-}, p o-$, whereas Smirnov (1970: 78) ranks it fourth after $s-/ z-/ z o-, z a-$, and $u-$. In any case, $p o$ - is not productive enough to compete with $s-/ z$ - at all. Merše (1995: 197) observes that in sixteenth-century Sln $p o$ - was second to $s$-/z- as a préverbe vide; my impression is that $s-/ z$ - is currently far more productive than $p o$ - in $S 1 n .{ }^{41}$ Regarding the productivity of $p o$ - in the western languages, Pol and $\mathrm{Cro} / \mathrm{Srb}$, it should be pointed out that, as discussed by Dickey (2001a), in these languages po- has retained its spatial SURFACE-CONTACT meaning, e.g., Cz poblinkat ${ }^{p}$ 'puke all over', Slk pomočit ${ }^{p}$ 'pee all over', Sor pocokrowaćp 'sugarcoat', Sln pokozlatip 'vomit all over', Pol popluskaćp 'splash all over', Cro/Srb popišatip 'pee all over'. This is in contrast to the eastern languages, where $p o$ - has lost the SURFACE-CONTACT meaning, and no longer has any clear spatial or lexical meaning (see section 5).

We may therefore generally oppose the productivity of $s-/ z$ - in the extreme western languages to the productivity of $p o$ - in the languages of the eastern group, again regardless of whether they too merged $*_{s} b^{-}$and $*_{j b z-}(\mathrm{Blr}, \mathrm{Ukr})$ or not (Rus, $\mathrm{Blg}$ and $\mathrm{Mac})$. The remaining languages, Cro and Srb, are not characterized by either $s-/ z$ - or $p o$ - as a dominant préverbe vide. In this respect, Cro and Srb are aspectually conservative. If we take into account that with regard to aspect usage Cro and (to a lesser extent) Srb closely resemble the western type, it becomes clear that, inasmuch as we can correlate aspectual morphology to usage type, it is in fact productive $p o$ - that positively correlates to the eastern pattern of aspect usage, whereas the western pattern includes languages with productive $s-/ z-(\mathrm{Cz}, \mathrm{Slk}, \mathrm{Sln}$, Sor) and without it (Cro, Srb). Note that the actual current situation regarding the productivity of perfectivizing $p o$ - is not of primary importance; rather, what is important is that it has been the dominant productive préverbe vide in the relatively recent past (for instance, since the sixteenth century). Prefixation with po- may be tied to eastern aspect usage in another respect as well: as Dickey and Hutcheson (2003) demonstrate, the languages of the eastern type are the same languages that have developed $p o$ - as a productive delimitative prefix. The following section will consider these overall correspondences with regard to the grammaticalization of aspect in the various languages.

\section{Innovative $s-/ z$ - and the Grammaticalization of Slavic Aspect}

As Mende (1999: 286) observes, the rise of grammatical aspect systems in Rus and the Slavic languages in general is not typical of the phenomena customarily examined in grammaticalization studies. Most case studies of grammaticalization (cf.,

${ }^{41}$ No assessments are available of the relative productivity of the prefixes, other than Plotnikova's (1971: 356) observations on the prefixation of loans verbs. She suggests that po- is the fourth most productive prefix in the perfectivization of loan verbs, after $i z-, s-/ z-$, and pre-. My disagreement with her on the relative productivity of $i z$ - and $s-z-$ - is irrelevant here. I would point out that her observation that po- primarily derives delimitatives from loan verbs in fact indicates that $p o$ - is not particularly productive with loan verbs, as $p o$ - is on the whole not very productive in the derivation of delimitatives in Sln (cf. Dickey and Hutcheson 2003). 
e.g., Hopper and Traugott 1993, Lehmann 1995) trace the development of single lexical units into markers of grammatical meaning (a representative case might be the evolution of English go from a verb of motion to a future auxiliary). Studies of the development of aspect in Rus, e.g., Bermel (1997), Nørgård-Sørensen (1997) as well as Mende (1999) must necessarily deal with the rise of a grammatical category which is not expressed by a single marker, but by a whole array of them (for example, Mende lists 12 prefixes which commonly function as préverbes vides in Rus). In this respect, the very nature of Slavic aspectual systems defies a simple application of the principles and precedents of grammaticalization theory. Thus, according to Mende (286-7),

[t]he grammaticalization of aspect consists of the rise of a whole category by means of derivational processes. At the risk of overstating the point, we may say that the development of Russian aspect involves a process whereby there are as many grammaticalized units as there are verbs-based on the derivational "doubling" of (almost) all verbs. The resulting grammatical status of these verbs is solely a consequence of the functional opposition evident between the source verbs and their derived correlates, and not of any regular morphological paradigm. Thus, there is no single unit that is grammaticalized, but rather numerous lexical units (i.e., all verbs) together come to comprise a hitherto nonexistent grammatical category without losing their lexical status at the same time. [Original emphasis, translation mine-SMD.]

Here Mende is following the approach taken by Bermel, who, in a meticulous examination of Rus verb usage and morphology in texts ranging from the eleventh to the seventeenth centuries, demonstrates that Rus aspect developed into a fully fledged grammatical category by the spread of the pf-impf opposition from the class of non-punctual telic predicates (i.e., Vendler's accomplishments) to punctual telic predicates as well as atelic predicates (cf. Bermel 1997: 463). Bermel, Nørgård-Sørensen and Mende all emphasize imperfectivizing suffixation as a key step in the establishment of aspect as a grammatical category in Rus (Slavic), following Maslov (1961). While I agree wholeheartedly with this view, it must be emphasized that the mass extension of the distribution of the aspect opposition in the Slavic languages by means of imperfectivizing suffixation firmly entrenched the impf-pf opposition qua opposition, but played no exclusive role in determining the precise meanings of the semantic categories being created. In this respect, I think the role of préverbes vides in the grammaticalization of aspect has been somewhat neglected, as I would argue that such prefixation has played a crucial role not only in formally creating one member of the aspect category (i.e., the pf aspect), but has also finely tuned the meaning of the pf aspect in the various languages. ${ }^{42}$

In order to give this hypothesis adequate consideration, I think it is necessary to reexamine some assumptions of recent work on the grammaticalization of Rus aspect. Bermel, Nørgård-Sørensen, Mende and Lehmann (1999) study the grammaticalization of Rus aspect by focusing on the gradual rise of the pf-impf aspect opposition as a grammatical category, and are thus concerned with the timing and overall processes which led to the establishment of aspect as one of the obligatory

${ }^{42}$ This is not meant to deny the role played by the semantic nature of the productive imperfectivizing suffixes in the respective languages. But since all of them (e.g., Rus -yva-/-iva-, $\mathrm{Cz}$ $-a v a-)$ have parallel origins as iterative morphemes, they may be ignored for some examinations of the east-west aspect division. In any case, they are beyond the scope of the present discussion. 
grammatical categories of Russian. They do not approach the rise of the impf-pf aspect opposition in terms of the grammaticalization of individual morphemes. As far as I can tell, each of these investigations tacitly assumes that the current functional division between the pf and impf aspect in Rus (i.e., the impf aspect predominating in the expression of events in process, habitual events, the simple confirmation of events in the past, whereas the pf aspect is largely restricted to the expression of single, completed events) is somehow the expected result of the (near) maximum grammaticalization of an aspect opposition expressing a totality distinction, ${ }^{43}$ though this idea is strongest in Mende's and Lehmann's discussions. In my view, this line of thinking is open to question, because it almost invariably leads to the conclusion that aspect in Slavic languages such as $\mathrm{Cz}$ (in which the functional division between the pf and impf aspect differs in some important ways from Rus, as pointed out in section 1) has not been grammaticalized to the degree of Rus aspect. Such a view may well eventually prove accurate or useful, but it does not change the fact that $\mathrm{Cz}$ has a stable system of aspect usage based on a distinction in totality-its system of usage is simply different from that of Rus. It is understandable that the system of usage in modern Rus would be considered the "finish line" in a grammaticalization study examining only Rus, but Lehmann (1999: 225) suggests that this kind of model is valid for all of North Slavic (though he nevertheless considers only Rus data).

To illustrate the problem, let us consider the fact that western languages such as $\mathrm{Cz}$ allow the pf in habitual contexts to a much higher degree than eastern languages such as Rus (cf., section 1, as well as Dickey 2000: 49 and the references cited there). Similarly, older stages of Rus allowed the pf in habitual contexts to a greater degree than modern Rus, gradually limiting it in this function (cf. Bermel 1997: 204, 280, 404, as well as Dickey 2000: 282 and the references cited there). If the overall similarity of the situation regarding aspect and habituality in modern $\mathrm{Cz}$ and ORus may be taken as likewise indicating an overall similarity of their aspect systems (which I think is a fair assessment, given several other points of similarity between aspect in ORus and modern Cz, cf., Dickey 2000: 282-3), then it is arguably misguided to assume an acute lack of systematicity in the ORus aspectual system. This should not be understood as a reactionary approach favoring older views of a "fully developed" aspectual system in Late Common Slavic or the early historical Slavic languages; rather, it simply means that one should be cautious of going very far in the opposite direction, assuming a kind of purely lexical category in ORus (and the other Slavic languages). In other words, we are not limited to viewing the grammaticalization of Rus aspect as the progression from a lexical totality-based category to a grammatical totality-based category; we may also assume the existence/rise along the way of grammatical meanings distinct from the meanings of the impf and pf in the final, grammaticalized state. In the case of Rus, an alternate approach would be to assume the progression from a lexical totality-based category to via an increasingly grammatical totality-based category to a grammatical category based on a distinction in temporal definiteness (sequentiality).

Thus, my concerns do not amount to a rejection of the approach shared by Bermel, Nørgård-Sørensen, Mende and Lehmann-or more precisely, the picture that

${ }^{43}$ That is to say, by expanding the system of aspectual pairs of verbs to a maximum. 
emerges when these studies are taken together. Rather, I would simply argue that in a theory of the grammaticalization of Rus (Slavic) aspect emphasizing the lexical expansion of both the pf and impf aspects on the one hand, and the overall expansion of the aspect opposition on the other, there ought to be room for a focus on the particular semantic development of the (proto-)pf aspect in these languages, especially in the context of the east-west aspect theory. Accordingly, I suggest that it may prove fruitful to analyze the semantic development of the pf aspect in the west and east in terms of the perfectivizing prefixes dominant in each group (respective1y). This approach involves the concept of grammaticalization in its more traditional sense, i.e., investigating the distribution of individual morphemes to see which, if any, have been grammaticalized as markers of the pf aspect, and leads to the following question: what significance did the grammaticalization of $s-/ z$ - as a marker of perfectivity have for the development of aspect in western Slavic?

In order to shed light on this issue, I believe a comparative cross-Slavic approach is still most productive. Therefore, let us briefly recapitulate the evidence regarding the status of $s-/ z$ - and $p o$ - as the dominant préverbes vides in the respective languages. Data from $\mathrm{Cz}$ and Rus will be taken as more or less representative of the situations in the western and eastern groups, respectively. The prefixes $s-/ z-$ and $p o-$ share some important traits, which are summarized in (7-8):

(7) In $\mathrm{Cz}, s-/ z$ - displays the following traits:

a. It is the only prefix which does not have a central spatial meaning (cf., e.g., Rusínová 2001: 224).

b. As pointed out in section 2.2.1, it forms many alternate pf verbs alongside other prefixes, e.g., zemrít $t^{p}-$ umřit $^{p}$ 'die'.

c. As pointed out in section 2.2.1, it has perfectivized the largest range of predicate types, including ordinary telic verbs (e.g., zbudovat ${ }^{p}$ build), inchoatives (e.g., zfamfrnĕt ${ }^{p}$ 'go crazy') and factitives (e.g., zfamfrnit ${ }^{p}$ 'drive crazy').

d. It remains highly productive, notably in the perfectivization of loan verbs (e.g., znormalizovat ${ }^{p}$ 'normalize').

(8) In Rus, po- displays the following traits:

a. It is the only prefix which does not have a central spatial meaning (cf., Voloxina and Popova 1997: 379, Camus 1998: 101, and Shull 2003: 158). ${ }^{44}$

b. As observed by Čertkova (1996: 123-4), po- is productive with the greatest number of predicate types, including ordinary telic verbs (e.g., postroit' ${ }^{p}$ 'build'), inchoatives (e.g., poveselet'p 'become cheerful'), factitives (e.g., poveselit'p 'make cheerful'), and delimitatives (e.g., poguljat'p 'stroll'); another class might be atelic verbs occurring with partitive objects (e.g., pokurit'p 'smoke'; cf. Anstatt 2003a).

c. According to data given by Tixonov (1998: 476), po- enters into more

${ }^{44}$ Recall from section 3.2 that according to Ivanova (1966: 124) Blg po- has no spatial meaning. Šerex (1951: 292) observes that po- has no spatial meanings in Ukrainian. 
variant prefix alternations than any other Russian prefix, (cf., e.g., pomeret'p-umeret'p 'die').

d. It remains productive (cf., Čertkova 1996: 123-4) in the perfectivization of loan verbs, (e.g., poformulirovat'p 'to formulate'). ${ }^{45}$

On the basis of (78) I suggest that $s-/ z$ - and po- occupy analogous positions in the aspectual systems of $\mathrm{Cz}$ and Rus respectively; their positions in the remaining languages of the respective groups are more or less identical. ${ }^{46}$

Accordingly, we may classify the Slavic languages into three types with regard to the systems of aspectual prefixation that they have developed: (1) the subsumptive type, (2) the $s-/ z$ - type and (3) the po- type. In the subsumptive type, no prefix has clearly lost its spatial meanings and developed into préverbe vide, acquiring primacy in the system of perfectivization. The aspectual system of OCS described in section 2.1 is of this type, as are the systems of Cro and Srb. This is not to say that no prefixes develop abstract resultative/perfectivizing functions in these languages (cf. resultative/distributive $i z$ - and distributive $p o$ - in Cro and Srb), but that such functions appear to be fairly clearly derived from their spatial prototypes. The $s-z$ - type consists simply of the western languages (basically $\mathrm{Cz}, \mathrm{Slk}$, Sln and Sor) in which $s-/ z$ - has become the préverbe vide. Similarly, this should not be misunderstood as a claim that no other prefixes function as perfectivizers, but rather that the others do so primarily on the basis of subsumption. In the po-type, the prefix po- has become the préverbe vide and shaped the meaning of the pf aspect regardless of whether $s-/ z$ - has also developed as a préverbe vide in that language (Ukr, Blr, and perhaps Pol) or not (Rus, Blg, Mac). This information is summarized in (9):

(9) Breakdown of Slavic According to Perfectivizing Prefixation:
a. SUBSUMPTIVE
Cro, Srb
b. $S-/ Z$ -
$\mathrm{Cz}$, Slk, Sor, Sln, (Pol), (Ukr), (Blr)
c. $P O-$
Rus, Ukr, Blr, Blg, Mac, (Pol)

In this breakdown, Ukr and Blr are listed under the $s$-/z-type in parentheses, because as was pointed out above the presence of po- as a préverbe vide in a language is maximally distinctive, (i.e., it supersedes $s-z$ - in the determination of the

${ }^{45}$ Čertkova observes that $p o$ - follows pro-, $z a-, s$ - and $o t$ - in the perfectivization of loan verbs (109). However, internet searches show that po- prefixes many of the verbs that she lists as prefixed with other prefixes. Thus, one can find poformatirovat' $p$ 'format' in addition to otformatiro$v^{\prime}{ }^{p}$, poformulirovat ${ }^{p}$ 'formulate' in addition to sformulirovat' $p$, etc. It is not only a matter of deriving delimitatives in $p o$ - alongside telic perfectives in other prefixes, as many of the competing perfectives in po- attested on the internet are not delimitative, e.g., [e]sli mne skažete, kak poformatirovat'p, ja podgotovlju polnyj spisok ... 'if you tell me how to do the formatting, I will prepare a full list' [n]o kakie-to vyvody poformulirovat'p poprobuju 'but I will try to formulate some conclusions', etc. A more detailed treatment and data cannot be attempted here. Note that if delimitatives prefixed in $p o$ - were included in the loan verb statistics, $p o$ - would certainly be higher in the list, as the vast majority of loan verbs can derive delimitatives in po-.

${ }^{46}$ As in the case of delimitatives (cf., Dickey and Hutcheson 2003), Pol demands a special treatment due to its clearly mixed status regarding the productivity of $s-/ z-$ and $p o-$, but this lies beyond the scope of the present discussion. 
meaning of the pf aspect); Pol is listed under both prefixes in parentheses to indicate its mixed patterning.

In my view, an adequate analysis of the morphology of Slavic aspect should in principle have consequences for a theory of the semantic distinctions expressed by aspect (and therefore accord in some non-trivial way with the facts of aspect usage in a given Slavic language), and vice-versa. What follows is an attempt to make sense of the basic correlation of the productivity of $s-z$ - with the languages that exhibit western patterns of aspect usage according the east-west aspect theory and the productivity of $p o$ - with the languages exhibiting eastern patterns of usage on the other, with reference to grammaticalization theory. From the standpoint of grammaticalization, it is very interesting that in a given Slavic language there are at most two candidates for a "grammaticalized" préverbe vide (Pol, and perhaps Ukr, $\mathrm{Blr})$; in the remaining languages there is either only one $(\mathrm{Cz}, \mathrm{Slk}$, Sor, Sln, Rus, $\mathrm{Blg}, \mathrm{Mac}$ ), or none (Cro, Srb). It is important to reiterate that by grammaticalized préverbe vide I mean a prefix which has either largely lost its primary spatial meanings ( $\mathrm{po}-$ ) or at least restructured its network in such a way that its abstract meaning appears to be a central, independent node in its network $(s-/ z-)$. I do not think this fact has ever even been recognized, let alone fully appreciated in Slavic aspectology. Given that in an individual Slavic language only one prefix tends to be "semantically bleached" while a variety of others also function as perfectivizers, a natural question that arises is whether this fact has any particular significance. I would argue that it does: the establishment of a single prefix as a preverbe vide "semantically organizes" the perfectivizing function of the remaining prefixes that function as perfectivizers on the basis of subsumption.

In this respect, recall again Shull's (2003) view that source, path and goal prefixes, in addition to their particular spatial configurations, all share an abstract schema, the TRANSITION FROM $S^{1}$ TO $S^{2}$. What occurred in $\mathrm{Cz}$ and the other western languages was that the establishment of $s-z$ - as a préverbe vide grammaticalized one prefix as the marker of a category of perfectivity based directly on telicity, i.e., the TRANSITION FROM $\mathrm{S}^{1}$ TO $\mathrm{S}^{2}$. I suggest that the introduction of grammaticalized $s-/ z$ - into the originally subsumptive system of perfectivizing prefixation in $\mathrm{Cz}$ reinforced the TRANSITION FROM $\mathrm{S}^{1}$ TO $\mathrm{S}^{2}$ as the aspectual meaning contributed by all other perfectivizing prefixes, which in turn helped to stabilize totality as the meaning of the pf in the western languages (recall again the east-west aspect theory outlined in section 1). In other words, what took place was a kind of semantic restructuring, or analogy, whereby the meaning contributed by $s-/ z$ - comes to define the semantic relationship between the pf and the impf: the semantic difference between $\mathrm{OCz}$ bledět $t^{i}$ and $z$ bledět $t^{p}$ 'turn pale' begins to serve as a model for the semantic difference between verbs such as OCz psáti and napsati ${ }^{p}$ 'paint'. In other words, with regard to aspectual semantics, the relation napsati ${ }^{p}$ : psáti $i^{i}$ is reanalyzed according to the model zbledét $i^{p}:$ bledét $i^{i}$. Given that in a completely subsumptive system napsati $^{p}$ already profiles the TRANSITION FROM $S^{1}$ TO $\mathrm{S}^{2}$, one is justified in asking how the grammaticalization of $s-/ z$ - as the systematic préverbe vide in fact changed the system, i.e., how it contributed to the grammaticalization of aspect in the western languages. In my view, it did not radically alter the nature and development of western aspect, but set the western pf firmly on a 
path to maintain TOTALITY as its categorial meaning. ${ }^{47}$

If we consider the grammaticalization of $s-/ z$ - as a marker of perfectivity with regard to the criterion of maximal regularity in signaling an opposition (cf. Lehmann 1999: 208)-in this case, the affixation of $s-/ z$ - to all possible verb stems-it becomes clear that despite its high productivity, $s-/ z$ - has not come close to establishing itself as the sole marker of perfectivity in the western languages; for instance, in $\mathrm{Cz}$, the language with the highest productivity of $s-z-, z a$ - has nevertheless also enjoyed considerable productivity in historical times. So $s-z$ - does not pass the maximal distribution test. There can be no doubt that the status of $s-z-$ as the leading perfectivizer of loan verbs is evidence of an impulse towards grammaticalization, but given the enormous inventory of verbs in which other prefixes signal perfectivity it is also highly unlikely that $s$ - $/ z$ - will ever attain "maximal distribution" and thus be grammaticalized in the traditional sense of the term.

And yet it does seem that the development of $s-/ z$ - must have some significance for the establishment and evolution of (western) Slavic aspect as a grammatical category. In this respect, Nichols' and Timberlake's (1991: 129) suspicion that processes of grammaticalization "may be less straightforward and obvious than is usually assumed" seems quite appropriate. Because if the suggestion made above is correct, i.e., that what is required to determine the grammatical meaning of the perfective aspect in a Slavic aspect system is a single préverbe vide, then it is probably misguided to assess the grammaticalization of $s-/ z$ - as a marker of perfectivity according to the usual criteria of obligatoriness, regularity of expression, etc. And the same is true for the grammaticalization of the aspect opposition as a whole: if one accepts Shull's view of an abstract schema of the TRANSITION FROM $S^{1}$ TO $S^{2}$ extracted from and shared by all spatial prefixes, and if it only takes one préverbe vide to semantically organize the perfectivizing function of prefixes, then the array of perfectivizing prefixes (cf. the remarks by Mende cited above) in a Slavic language seems much less arbitrary or chaotic. ${ }^{48}$ This point cannot be stressed enough. Taking this line of thought further, I suggest that what was decisive for the establishment of $s-/ z$ - as a grammaticalized préverbe vide was the development that resulted in it functioning to perfectivize verbs of a maximum number of predicate types, which is not quite the same as simply perfectivizing some maximum number of verbs. ${ }^{49}$ (Again, I view inchoatives as particularly important in determining which prefix is a préverbe vide in a given Slavic language.) To all appearances, in the western languages it was the purely phonetic accident of jer-fall that precipitated the distribution of $s-z-$ as a perfectivizing prefix over such a broad range of predicate types: ordinary telic verbs, inchoatives and factitives.

I think the spread of $s-/ z-$ in $\mathrm{Cz}$ and the western languages may be successfully analyzed as a case of what Nichols and Timberlake (1991) term retextualiza-

\footnotetext{
${ }^{47}$ The precise evolution from TRANSITION FROM $S^{1}$ TO $S^{2}$ to totality as the meaning of the western pf certainly involves the interrelation between prefixed pf verbs and the innovative derived impf verbs; this issue is not taken up here.

${ }^{48}$ By the same token, the fact (mentioned in 2.2.3) that $s$-/z-competes with po- in Pol but is nevertheless currently the productive prefix with loan verbs is also less puzzling.

${ }^{49}$ Accordingly, one may consider the high productivity of $s$ - $/ z$ - with loan verbs in the western languages as the consequence of its grammaticalization and not a process of grammaticalization per se.
} 
tion in their analysis of the expansion of the Rus predicative instrumental. Retextualization refers to a two-part process of innovation and conventionalization. The innovation involves a new usage (token) of a linguistic unit which is analogous to but not identical to preexisting exemplars of that linguistic unit; the new token is then conventionalized as an exemplar which serves in turn as a model for newer analogical innovations. I see no reason why this model of grammatical development should not be applicable to changes in the distribution and functions of aspectual morphology as well, and accordingly suggest that what happened with western Slavic $s-z-$ is that this original accidental innovation was conventionalized, or retextualized, as a préverbe vide in those languages. Moreover, I would argue that the analogy outlined above whereby the pf meaning of all the other prefixes (e.g., $\mathrm{OCz}$ psáti $^{i} /$ napsati $^{p}$ ) was slightly reconfigured on the model of $s$-/z- (e.g., OCz bledě$\left.t i^{i} / z b l e d e ̂ t i^{p}\right)$ is likewise a case of retextualization.

The retextualization hypothesis makes sense with regard to Šlosar's (1981: $130-4)$ account of the growth in the productivity of $s-/ z-.^{50} \mathrm{He}$ surmises that in early $\mathrm{OCz} s-/ z$ - spread more or less mechanically through semantic classes of $\mathrm{OCz}$ verbs. Thus, $s-z$ - originally functioned as an empty perfectivizer with verbs of destruction/consumption and loss, e.g., zbósti ${ }^{p}$ 'stab to death', zemrieti ${ }^{p}$ 'die', zhubiti ${ }^{p}$ 'devastate, kill', zjéstip 'eat up', etc. From this group, $s-/ z$ - spread to an antonymous group of verbs denoting "emergence", e.g., zjevitip (sê) 'appear', zmnožitip 'multiply', $z m y s l i t i^{p}$ 'think up', etc. Subsequently it spread to a group of verbs expressing a negative result, e.g., zdrážditi ${ }^{p}$ 'irritate', zkaliti $i^{p}$ 'cloud, muddy', ztlačiti ${ }^{p}$ 'crush underfoot'. From here it then spread to the deadjectival inchoatives (e.g., ztvirdét $t^{p}$ 'harden') and factitives (e.g., změkčiti ${ }^{p}$ 'soften'). Accepting Šlosar's chronology of the spread as an approximation of what really happened, I suggest the retextualization proceeded as follows: jer-fall and the phonetic coalescence of $*_{s b-}$ and $*_{j b z}$ - produced a class of resultative verbs denoting the destruction/consumption of the object, most of which were originally prefixed with ${ }^{*} j b z-$ (e.g., zbóstip 'stab', zjestip 'eat up'). The accelerated disassociation of $z-(\leftarrow * j b z-)$ with its etymological meaning of elativity led to its productivity as a resultative prefix with such verbs, where the result is very tangible. Verbs of destruction/consumption originally prefixed with $*_{s b-}$, e.g., sžéc $i^{p}$ 'burn up', reinforced this productivity, as their resultativity (telicity) was reanalyzed as a case the new resultative prefix $z$ - and their connection to the etymological basis of their telicity (either the centripetal or downward-ablative meaning of $*_{s b-)}$ was lost. This in fact was the coalescence creating $s-/ z-$, and the resultative verbs of destruction/consumption were the first "exemplars" of resultative $s-/ z$-. Subsequently, verbs of emergence, many of which according to Šlosar (1981: 132) had been originally prefixed with ${ }^{*} s b$-, e.g. $z m y s l i t i^{p}$ 'think up' (cf. OCS $s$ bmysliti ${ }^{p}$ ) were retextualized as resultatives analogous to the verbs of destruction/consumption. Verbs of negative result were probably reanalyzed as resultatives in $s-/ z$ - simultaneously to the aforementioned process (I do not think the time of the assimilation of this class of verbs into the new resultatives in $s-/ z$ - is crucial for the analysis, and since according to Šlosar they functioned as synonyms of the verbs of destruction, I consider it possible that they were retextualized relatively early). In other words, I suggest

${ }^{50}$ Šlosar refers only to $z-$, but this does not affect the hypothesis given here; his data for $s$ (cf., Šlosar 1981: 124) are incorporated easily enough, as they involve the same classes of verbs. 
that the retextualization of resultative verbs prefixed in $s$ - $\left(\leftarrow *_{s b-}\right.$; their resultativity was originally metaphorically derived from the centripetal or downward-ablative meaning of the prefix) as resultatives prefixed with the new abstract prefix $z$-was crucial for the semantic coalescence. This ongoing process can account for Šlosar's (1981: 105) observation, mentioned in section 2.1.1, that $z$ - as a resultative prefix was reinforced by verbs that originally had $s$ -

As pointed out several times in the preceding sections, the next and most significant step was the establishment of $s-z$ - as the inchoative prefix. This occurred by virtue of the fact that $s-/ z$ - was becoming firmly established as an abstract resultative prefix, which was ideal for the perfectivization of inchoatives, given the fact that they had no natural association with any kind of metaphorical spatial telicity (cf. section 2.1) as well as the fact that various exemplars already in $s-/ z-$ had already been created by jer-fall, e.g., zsechnúti ${ }^{p}$ 'dry out' (cf., OCS is'sxnoti ${ }^{p}$ ). This then led to diverse verbs being prefixed with $s-/ z$ - to form resultatives and in time, simple perfectives. To sum up, jer-fall resulted in a nascent group of resultative verbs in $s-/ z$ - which served as exemplars for the retextualization of other verbs containing the prefix; as verbs of other classes prefixed with the new $s-/ z$ - began to serve as exemplars of resultative $s-/ z-$, the growing group then generally became a productive derivational model for perfectivizing prefixation.

The second component of the retextualization process involves $s-/ z-$, on the one hand, and verbs containing other prefixes on the other. According to the analogy hypothesized above, the aspectual values of the pair psátilinapsati ' $p a i n t$ ' were re-

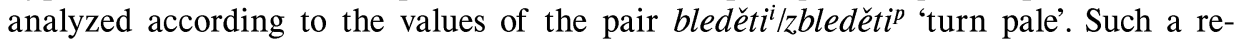
analysis may be easily analyzed as a case of retextualization, in which verbs prefixed in $s-/ z$ - serve as exemplars for a retextualization of pf verbs prefixed with other prefixes. As pointed out above, the shift in meaning is slight, and is probably better viewed as a process leading to the reinforcement of resultativity as the prototypical meaning of the western pf as a opposed to anything like a seismic shift in aspectual semantics. The emergence of resultativity as the meaning of the perfective would easily lead to a subsequent development of totality as the meaning of the western $\mathrm{pf}^{51}$ The fact that the grammaticalization of $s$ - $/ z$ - as the dominant préverbe vide resulted in a reinforcement of an already existing meaning (telicity/resultativity) as opposed to a semantic shift allows us to make sense of the fact that the subsumptive languages, Cro and Srb, pattern very closely to the languages of the western group, i.e., the $s$-/z-type, $\mathrm{Cz}$, Slk, Sor, Sln.

The hypothesis outlined above may seem trivial, given the "minimal" semantic impact of innovative $s-/ z$ - on the system of western aspect. However, I think it is more realistic than hypothesizing a more significant and "teleological" grammaticalization process within the system of perfectivizing prefixation in the western languages. The western languages merely took steps to grammaticalize the meaning of

${ }^{51}$ At this point it must be stressed that the hypothesis advocated here should not to be understood as a claim that it was $s-/ z$-alone that determined the semantic development of the western pf. There were other important factors involved, including the role of $-n Q$ - as a productive perfectivizer (cf., Dickey 2001b) and-perhaps most importantly-the role of German (and very possibly also Romance) language interference in the western languages. These issues cannot be discussed here. 
the perfective that was already shared by telic prefixes, as opposed to creating a new semantic opposition by means of that grammaticalization. In my view, the semantic organization of the pf aspect by means of $s-/ z$ - may help to explain why prefixes in the western languages have retained a relatively strong spatial character (for instance, all the western languages have retained the surface-contact meaning of po-). This has been pointed out by Shull (2003: 228-30) concerning prefixation in $\mathrm{Cz}$, which she concludes is more noticeably spatial than prefixation in Rus, which is on the average more abstract. If western languages such as $\mathrm{Cz}$ grammaticalized $s-/ z-$ as the marker of the TRANSITION FROM S $\mathrm{S}^{1}$ TO $\mathrm{S}^{2}$, which established telicity as the abstract aspectual profile of their perfectivizing prefixes, the fact that the aspectual profile of these prefixes was an element of meaning compatible with their original spatial meanings would allow them to retain these spatial meanings at no cost to any additional grammatical function(s) they might have or develop.

This view of the development of the western pf also helps to explain why delimitatives in po- never became highly productive in the western languages (cf. Dickey and Hutcheson 2003), for the following reasons. If the grammaticalization of $s-/ z$ - reinforced the TRANSITION FROM $S^{1}$ TO $S^{2}$ and thus resultativity as an early prototypical meaning of the western pf, then it makes sense that delimitatives in po- comparable to those in Rus never became highly productive in the western languages, as their profile, the absence/negation of a situation $(-S)$ followed by the situation in question $(S)$ followed by the absence of the situation $(-S)$, i.e., $-S \rightarrow S \rightarrow$ $-S$, differs considerably from the TRANSITION FROM $S^{1}$ TO $S^{2}$. The difference between the profile $-S \rightarrow S \rightarrow-S$ and the TRANSITION FROM $S^{1}$ TO $S^{2}$ is too great to allow such delimitatives to be derived on a large scale as straightforward instantiations of the TRANSITION FROM $S^{1}$ TO $S^{2}$ hypothesized as the shared schema of perfectivizing prefixes. ${ }^{52}$ Further, the assumption that grammaticalized $s-/ z$ - reinforced resultativity as the primary meaning of the western pf accords with the "telic" nature of delimitatives in $p o$ - in the western languages. For instance, unlike eastern delimitatives, delimitatives in the western languages may easily stress the full extension of a predicate over a particular period of time, as shown in (10):

(10) Dostal horkou nemoc a poležel ${ }^{p}$ si několik týdnů, než se uzdravil. 'He came down with typhoid fever and lay for several weeks before he recovered.'

Thus, western delimitatives have retained a prominent telic sense, which is arguably supported by the telic nature of the western pf as influenced by $s-/ z-$.

Despite the admittedly minimal impact of $s-/ z$ - on the meaning of the pf in the western languages, if the hypothesis of the grammaticalization of $s-/ z-$ advocated here is correct, we should in principle be able to find other differences between the aspectual systems of the languages of the $s$-/z-type on the one hand and those of the other languages (belonging to the subsumptive and po-types) on the other. One subtle yet important difference involves the productive derivation of pf

\footnotetext{
${ }^{52}$ This semantic incompatibility does not render the derivation of such delimitatives impossible. Rather it simply means that they will be marginal subtypes of the perfective in the western languages: delimitatives do not typically denote a change to a new, positively characterized state, but only the (trivial) change from a situation to its absence.
} 
verbs of abstract change of state. $\mathrm{Cz}$ and Slk, the epicenter of the spread of $s-/ z-$, have developed deadjectival inchoatives and factitives as classes of verbs much more than the other Slavic languages. ${ }^{53}$ For example, $\mathrm{Cz}$ derives zevšednět ${ }^{p}$ 'become daily/quotidian' directly from the adjective všední 'daily' (i.e., the clearly adjectival stem všedn-; cf. Slk zovšedniet ${ }^{p}$ with the same meaning), whereas this notion must be expressed periphrastically in other Slavic languages, e.g., Rus stat'p obydennym, $\mathrm{Cro} / \mathrm{Srb}$ postati ${ }^{p}$ svakidašnji; cf. also $\mathrm{Cz}$ zvodnatět $^{p}$ 'become watery' $(\leftarrow$ vodnatý 'watery'; Slk zvodatniet ${ }^{p}$ ) as opposed to Rus stat'p vodjanistym and Cro/Srb postati ${ }^{p}$ vodenast. This model is productive with loaned adjectives, cf., $\mathrm{Cz}$ znervóznět ${ }^{p}$ 'become nervous' ( $\leftarrow$ nervózní 'nervous'; Slk znervózniet ${ }^{p}$ ), as opposed to Rus stat'p nervnym, Cro/Srb postati ${ }^{p}$ nervozan. The derivation of deadjectival factitives with $s-/ z$ - is also quite productive in $\mathrm{Cz}$ and $\mathrm{Slk}$, in contrast to the other Slavic languages: cf., for example, $\mathrm{Cz}$ zpř́stupnit ${ }^{p}$ 'make accessible' $(\leftarrow$ přístupný 'accessible'; Slk sprístupnit $^{p}$ ), as opposed to Rus sdelat ${ }^{p}$ dostupným, Cro/Srb učiniti $i^{p}$ dostupnim, as well as $\mathrm{Cz}$ znervóznit ${ }^{p}$ 'make nervous' (Slk znervóznit ${ }^{p}$ ), as opposed to Rus privesti ${ }^{p}$ $v$ nervnoe sostojanie/rasstroit ${ }^{p}$, Cro/Srb iznervirati ${ }^{p} /$ učiniti ${ }^{p}$ nervoznim. ${ }^{54}$ Though for individual predicates other Slavic languages will have inchoative or factitive verbs equivalent to the $\mathrm{Cz}$ and Slk verbs in s-/z- (e.g., Ukr zvodnity 'become watery', $\mathrm{Cro/Srb}$ iznervirati $^{p}$ 'make nervous'), the examples given above accurately reflect the status of inchoatives and factitives as a systematized element of the $\mathrm{Cz} / \mathrm{Slk}$ aspectual system as opposed to the other Slavic languages.

Further evidence of the integration of inchoatives and factitives in $s-z$ - into the $\mathrm{Cz} / \mathrm{Slk}$ aspectual system are verbs prefixed with $z n e-{ }^{55}$ Examples of inchoatives are znemravnét ${ }^{p}$ 'become immoral' ( $\leftarrow$ nemravný 'immoral'; Slk znemravniet $\left.t^{p}\right)$ and znehybnět ${ }^{p}$ 'become motionless' $\left(\leftarrow\right.$ nehybný 'motionless'; Slk znehybniet $\left.{ }^{p}\right)$; representatives of factitives are znemravnit ${ }^{p}$ 'make immoral' (Slk znemravnit $^{p}$ ) and znehybnit ${ }^{p}$ 'make motionless' (Slk znehybnit ${ }^{p}$ ). Such verbs have few direct equivalents in East and South Slavic, ${ }^{56}$ where periphrastic translations are required, cf., e.g., Rus $s t a t^{\prime} / s d e-$ lat'p beznravstvennym 'become/make amoral', stat'p/sdelat'p nepodvižnym 'become/make motionless' and Cro/Srb postati ${ }^{p}$ nemoralan/učiniti ${ }^{p}$ nemoralnim 'be-

${ }^{53} \mathrm{Pol}$ and Ukr have also developed some inchoative verbs of this type, but not to the extent of $\mathrm{Cz}$ and $\mathrm{Slk}$, as pointed out in 2.2.3 and 3.1.

${ }^{54}$ Sor also appears to derive deadjectival inchoatives and factitives in a manner resembling $\mathrm{Cz}$ and $\mathrm{Slk}$, cf., e.g., zbrunjećp 'become brunette', zbrunićp $^{p}$ 'dye brunette', spřistupnićp 'make accessible, etc., though it is impossible at this point to assess the productivity of $s$ - $/ z$ - in this role more precisely relative to $\mathrm{Cz}$ and Slk.

${ }^{55}$ Sor derives some such verbs, e.g., znjemjernic $p$ 'upset' znjesmjertnićp 'make immortal'. Pol derives some verbs in znie-, e.g., znieksztatcićp 'deform', etc., but only a few are actually deadjectival, e.g., znieczulićp 'make numb' $(\leftarrow c z u \nmid y$ 'sensitive'); in Pol this derivational model seems more marginal than in $\mathrm{Cz}$ and Slk.

${ }^{56} \mathrm{Ukr}$ derives some verbs in zne-, e.g., znestjamytysja ${ }^{p}$ 'lose consciousness', zneslavyty ${ }^{p}$ 'defame' (both denominal), but very few clearly deadjectival verbs, of which an example is zneruxomyty $^{p}$ 'make motionless' ( $\leftarrow$ neruxomyj 'motionless'). One item which indicates a lack of semantic consistency as far as the element of negation is concerned is zljudnity ${ }^{p}$, which means 'become depopulated' and not 'become populated' $(\leftarrow$ ljudnyj 'populated'); I think the only plausible way of arriving at such a meaning is to assume that here $z$ - expressed ablativity or elativity (in a fashion similar to English depopulate), which is an indication that $s-/ z$ - in $\mathrm{Ukr}$ is not quite as free of spatial meaning as it is in $\mathrm{Cz}$. 
come/make immoral', postati ${ }^{p}$ nepokretan/učiniti ${ }^{p}$ nepokretnim 'become/make motionless'. Hauser (1995: 201) observes that in $\mathrm{Cz}$ inchoatives and especially factitives in $z n e$ - are increasing in productivity, and observes that contemporary usage attests verbs in $z n e$ - not given in dictionaries, e.g., znepruchodnit 'make impassable', znesplavnit $^{p}$ 'make unnavigable', znerovnoprávnit ${ }^{p}$ (Slk znerovnoprávnit ${ }^{p}$ ) 'make unequal', zneviditelnit ${ }^{p}$ (Slk zneviditelnit ${ }^{p}$ ) 'make invisible'. Such productivity contrasts with the almost complete lack of such verbs in East and South Slavic.

The fact that these models of derivation are productive in precisely in $\mathrm{Cz}$ and Slk lends support to the hypothesis advocated here that the grammaticalization of $s-/ z$ - as a préverbe vide privileged the TRANSITION FROM $S^{1}$ TO $S^{2}$ as an independent, abstract aspectual meaning in the western languages. Moreover, I suggest that the salience of this abstract meaning in the aspectual systems of $\mathrm{Cz}$ and Slk is responsible for the creation of verbs in zne-referring to very specific domains, as in the case of zneschopnit ${ }^{p}$ 'declare unfit for work/give someone a sick note' $(\leftarrow n e$ schopný 'unfit'). To recapitulate, $\mathrm{Cz}$ and $\mathrm{Slk}$ are producing a diversity of predicate meanings involving inchoatives and factitives with $s-z-$ and $z n e-$ : they derive inchoatives and factitives involving one and the same notion, e.g., $\mathrm{Cz} z$ zrrísnét $t^{p}$ 'become strict' and zprísnit ${ }^{p}$ 'make strict', as well as positive and negative correlates, e.g., Cz zrovnoprávnit ${ }^{p}$ 'make equal (before the law)' and znerovnoprávnit ${ }^{p}$ 'make unequal (before the law)'. In my view, this productivity of change of state verbs in $s-/ z$ - and especially $z n e-$ in $\mathrm{Cz}$ and Slk indicates that these languages are extending the scope of $s-/ z$ - in its meaning of the TRANSITION FROM S $\mathrm{S}^{1}$ TO $\mathrm{S}^{2}$, which would be unlikely if this meaning were not relatively salient in the network of the perfective aspect. On the other hand, the fact that other Slavic languages derive such verbs to a lesser extent or not at all makes sense if we assume that their aspectual systems lack a grammaticalized prefix signaling the TRANSITION FROM $\mathrm{S}^{1}$ TO $\mathrm{S}^{2}$ (e.g., $\mathrm{Cro} / \mathrm{Srb}$ ), or are oriented around another conceptual category (e.g., Rus; see below).

Another consequence of the grammaticalization of $s-/ z$-can be seen in some subtle differences in the relative importance of prefixation for the aspectual systems of the languages of the $s-/ z$ - type and those of the subsumptive type, i.e., Cro and $\mathrm{Srb},{ }^{57}$ regarding the status of biaspectual verbs in the respective aspectual systems. Grickat (1957: 66, 104-5) observes not only that newer loans are quite resistant to prefixation in $\mathrm{Cro} / \mathrm{Srb}$ (e.g., niklovati ${ }^{i / p}$ 'plate with nickel', denuncirati ${ }^{i / p}$ 'denounce') but also that $\mathrm{Cro} / \mathrm{Srb}$ has a higher number of older biaspectual verbs (e.g., krstiti ${ }^{i / p}$ 'baptize', čestitati ${ }^{i / p}$ 'congratulate') than any other Slavic language. ${ }^{58}$ In my view, Grickat (116) rightly attributes the high level of biaspectuality in Cro/Srb to the lack of sufficiently abstract perfectivizing prefixes in the language(s), and recognizes this

${ }^{57}$ Likewise, there ought to be the same kind of differences between Cro and Srb on the one hand and the po- languages such as Rus on the other, as prefixation is just as important for aspect (if not more so) in the latter as in the $s$-/z- type, and indeed there are (cf. Grickat 1957: 119-28); but the focus here is on the consequences of $s$ - $z$ - as a grammaticalized préverbe vide in the western languages as opposed to languages lacking that préverbe vide as well as any other (i.e., $p o-$ ).

${ }^{58}$ Ivančev (1971: 170, fn. 1) disputes Grickat's conclusion that biaspectual verbs are more numerous Cro/Srb than in Blg, ascribing to Blg "first place" in this regard. The issue cannot be resolved here, but I think there are several reasons for accepting Grickat's conclusions, or at least for the assumption that biaspectuality is more prominent in the aspectual system of Cro/Srb than 
as an archaic feature of Cro/Srb (128). In contrast, languages of the $s-/ z$ - type display a relatively low level of biaspectuality, both in older verbs and newer loan verbs, the latter of which are consistently, if slowly, affixed with aspectual morphology, primarily, in fact $s-/ z-$, cf., e.g., zformatovat ${ }^{p}$ 'format' and zregistrovat ${ }^{p}$ 'register'.

If we assume that $s-/ z$ - contributed significantly to the determination of the meaning of the pf in the western languages, we can do the same for the development of po- as a préverbe vide in the eastern languages. It was shown above that Rus po- shares some important qualities with $\mathrm{Cz} s-/ z-$, which make it unique within the Rus system of prefixation. Another important indication of the unique status of po- among Rus perfectivizing prefixes is the fact that, as Camus (1998: 101) points out, po- is the only Rus prefix for which the aspectual pairs consisting of an impf simplex and a prefixed pf verb outnumber the pairs consisting of a prefixed $p f$ verb and its suffixed impf correlate. The importance of this fact cannot be stressed enough in an evaluation of the status of $p o$ - in the Rus aspectual system. In view of these facts, I consider it possible that the grammaticalization of $p o$ - as the dominant préverbe vide in the eastern languages has had systemic effects analogous to those of $s-/ z$ - in the western languages, the difference being that its impact on the development of semantic category of the eastern pf has been greater. And like the spread of $s-/ z-$, the spread of eastern perfectivizing $p o$ - may be analyzed as a case of retextualization. The following remarks outline a hypothesis of the grammaticalization of $p o$ - in the eastern languages; as the development of perfectivizing $p o$ - is to all appearances a considerably more complex phenomenon, a detailed treatment is impossible.

Dickey (2000: 282-7; see also the references cited there), suggests that the origin of the east-west aspect division lies chiefly in changes that have occurred in eastern aspect usage approximately since the seventeenth century. The current pattern of eastern aspect usage described in section 1 is to a considerable extent the result of changes that involved on the one hand the expansion of the impf in the non-actual present and the general-factual function, and on the other the increasing restriction of the pf aspect to contexts of sequentiality, as well as the loss of aspectual pairs of verbal nouns. (It is unlikely that these changes in usage took place at the same time; rather, the elimination of the pf aspect from contexts of habituality was probably a slow process that began relatively early, whereas other changes, such

in the Blg system. First, some very common Cro/Srb biaspectual verbs have aspectually distinct cognates in Blg, cf., e.g. Cro/Srb čestitati ${ }^{i / p}$ vs. Blg čestitja $a^{p}$ 'congratulate', Cro/Srb jebati ${ }^{i / p}$ vs. Blg $e b a^{i}$ 'fuck', and $\mathrm{Cro} / \mathrm{Srb}$ vidjeti $i^{i / p}$ vs. Blg vidja ${ }^{p}$ 'see'. Second, though both $\mathrm{Cro} / \mathrm{Srb}$ and $\mathrm{Blg}$ have "impf" simplex verbs that are used like pf verbs in sequences of events, e.g., Cro/Srb jesti $i^{i}$ Blg $j a^{i}$ 'eat', there are paired simplex verbs in $\mathrm{Cro} / \mathrm{Srb}$ for which this is true in contrast to their equivalents in Blg; an example is $\mathrm{Cro} / \mathrm{Srb}$ pitati ${ }^{i}-\left(\right.$ paired with upitati $^{p}$ ), which occurs in past-tense sequences of events quite easily, whereas Blg clearly prefers the popitam ${ }^{p}$ 'ask'-(paired with pitam $^{i}$ ) in such narrative sequences. Third, Blg does prefix loan verbs to a limited extent, e.g., otreagiram $^{p}$ 'react', as does Cro/Srb, e.g., izorganizirati ${ }^{p}$ 'organize', but also shows a tendency to suffix loan verbs in order to create derived impf verbs, e.g., ekranizirvam ${ }^{i}$ 'produce for the screen', registrirvam ${ }^{i}$ 'register' and servirvam ${ }^{i}$ 'serve'. Finally, it is worth pointing out that since Blg retains the aorist/imperfect distinction for biaspectual verbs, such verbs are arguably less consequential for an assessment of the Blg aspectual system than they are for Cro/Srb, where most contemporary urban speakers have reduced the past tense system to a single preterite. 
as the expansion of the impf general-factual and the loss of pf verbal nouns, occurred later, as late as the eighteenth century.) Dickey and Hutcheson (2003) suggest that the productive derivation of delimitatives in $p o$ - in the eastern languages since the seventeenth century stands in some connection with the innovations in eastern aspect usage, as well as the grammaticalization of aspect in those languages. It is interesting that Bermel (1997) concludes that Rus aspect was grammaticalized much later than is commonly assumed, around the sixteenth century. Bermel's conclusions accord with those reached independently by Nørgård-Sørensen (1997), who argues that aspect crystallized as a grammatical category in Russian in the seventeenth century. The temporal coincidence of the rise of delimitatives in po- with the recently suggested chronology of the grammaticalization of Rus aspect cannot be accidental.

Let us first discuss the place of delimitatives in the aspectual system of the eastern languages (much of this discussion is drawn from Dickey and Hutcheson 2003, to which the reader is referred for details). Though Russian/Slavic aspectology has traditionally viewed delimitatives in po-as just one of several Aktionsarten, it is clear that they have a special status as pf verbs which qualify as "aspectual partners" of their impf source verbs (when these are construed as atelic predicates), and this fact has been recognized in some recent work on the subject (e.g., Lehmann 1988 and Čertkova 1996). The development of the productive derivation of delimitatives in po- in East Slavic and Blg began in the sixteenth century and resulted in the spread of the aspect opposition to a whole predicate class, atelic activities (e.g., sidet $^{\text {'i }}$ 'sit'). Before the advent of delimitatives, the aspect opposition was largely limited to telic predicates (accomplishments, e.g., stroit' 'build', and achievements, e.g., skakat' 'jump'), i.e., predicates that are readily viewed as completed events. The spread of the aspect opposition to atelic activity predicates thus represents an important step in the grammaticalization of the aspect opposition, as it considerably extended its distribution throughout the verbal inventory.

Sigalov (1975) documents the spread of delimitative po- in Rus. Delimitatives were originally derived from stative verbs, as early as Common Slavic; ORus examples are poležati ${ }^{p}$ 'lie for a while' and pobolět $i^{p}$ 'be ill for a while'. Sigalov (171) hypothesizes that the delimitative meaning developed next in $p o$-derivatives of indeterminate verbs of motion, e.g., ORus poběgati ${ }^{p}$ 'run for a while', poxoditip "walk for a while', and "verbs of psychological activity", e.g., ORus pomolitisja "pray for while' poveselitisja $a^{p}$ 'be cheerful for a while', approximately from the sixteenth to the seventeenth centuries. Only subsequently (in the seventeenth and eighteenth centuries) did the delimitative meaning develop in $p o$ - derivatives of verbs of speech (e.g., pobesédovati ${ }^{p}$ 'converse for a while', pogovoriti ${ }^{p}$ 'talk for a while'), verbs of sound (e.g., pogreméti $i^{p}$ 'thunder for a while', pogudět $i^{p}$ 'drone for a while') and verbs of physical activity (e.g., pokopati ${ }^{p}$ 'dig for a while', pokositi ${ }^{p}$ 'mow for a while'). Note that all these verbs are attested in ORus in other meanings (usually resultative), so what we are dealing with is the reanalysis of such derivatives as delimitatives, and not usually their new derivation. I suggest that part of what happened was that these various classes of verbs were successively retextualized as delimitatives on the basis of already existing delimitative exemplars.

Why delimitativity would become so productive in the eastern languages is a question which cannot be anwered here in any definitive way. However, Sigalov 
(1975) and Dmitrieva (2000) assume that the origin of modern delimitative po- lies in the loss of the resultative meaning of the prefix with individual verbs, which was derived more or less directly from older spatial meanings of the prefix/preposition, its surface-contact meaning and/or its allative meaning. ${ }^{59}$ Some spatial meanings of the preposition po that existed in ORus, such as its allative meaning (e.g., po Rogaticju 'all the way to Rogatica'), were lost well before the eighteenth century, so it is possible that the loss of the allative meaning of the prefix/preposition deprived the old resultative $p o$-derivatives of the spatial metaphorical basis for their telicity, at which point they began to be reanalyzed as atelic delimitatives in po-.

I believe that an important exemplar for the aforementioned processes of retextualization were in fact determinate verbs of motion in po-, e.g., ORus poit $i^{p}$ 'go', which are not commonly associated with delimitatives. Yet data from ORus show that poiti ${ }^{p}$ could at one time express the duration of the motion in fashion resembling ordinary delimitatives, as shown in (10), one of many such sentences occurring in Afanasij Nikitin's Journey across Three Seas (fifteenth century):

(11) A is Čjuvilja pošli ${ }^{p}$ esmja do Pali 8 dni, do indějskyja gory.

'And from Chaul we went eight days to Pali, to the Indian mountain[s].'

[BLDR 7: 354]

Note that the emphasis of the duration of the situation here resembles that in the modern $\mathrm{Cz}$ ex. in (9). Thus, it is not at all misguided-especially in a diachronic analysis-to seek a semantic element shared by determinate motion verbs and other types of verbs prefixed with po-. Shull (2003:147-80) argues that the profile of powith determinate motion verbs in modern Rus is not merely ablativity, but the beginning of the motion as well as some indeterminate amount of it (cf. Shull 2003: 153). Shull's profile for po- with motion verbs is given in Figure 5.

Figure 5: Shull's (2003: 153) Schema for Rus po- with Motion Verbs

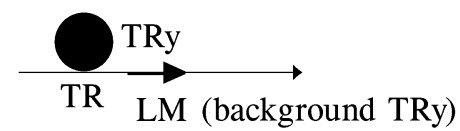

According to this schema, a trajector (TR) traverses some amount of a trajectory (TRy), for which the landmark (LM) is not an ordinary landmark in space but in fact the full trajectory of the motion expressed by the verb, i.e., the normal extent of the action itself. According to Shull (173), this schema unites the meaning of poin determinate verbs of motion (e.g., pojti ${ }^{p}$ 'go'), inchoatives (e.g., pokrasnet' ${ }^{p}$ 'blush'), delimitatives (e.g., počitat'p 'read for a while') as well as telics (e.g., postro$i t^{\prime} p$ 'build'), in the sense that the contribution of $p o$ - is the meaning that "some amount of the action has been completed", and the individual interpretations of the verbs are functions of the predicate types themselves (for details see Shull 2003: 163). Shull's synchronic view that the aspectual meaning of determinate motion verbs in po- is essentially the same as that of delimitative verbs is illuminating, and is another reason for linking determinate motion verbs in $p o$ - and delimitatives in a diachronic analysis.

${ }^{59}$ Note that this is also a claim made by Němec (1954). 
An oddity of the prefix po- with determinate motion verbs, e.g., ORus poiti ${ }^{p}$ 'go', is that the original spatial meaning of the prefix in this case (something akin to the contact meaning of the modern preposition po 'along') was redundant inasmuch as motion always occurs along a path. As pointed out in (8a), Shull (158) observes that the prefix currently has no spatial meaning in motion verbs. I suggest that the spatial meaning of the prefix was lost relatively early in determinate motion verbs, so that ORus poiti ${ }^{p}$ 'go' took on a meaning of temporal ingressivity (as distinct from spatial ablativity), yielding the current meaning of 'beginning of the motion plus some indefinite amount'. I consider it possible and in fact very likely that determinate motion verbs (which are very common in discourse) were very salient exemplars in the process of retextualization of older po- resultatives as delimitatives. $^{60}$

Let us now consider the consequences of the grammaticalization of po- as the eastern préverbe vide. The hypothesis advocated here is that, parallel to the case of $s-/ z$ - in the western languages, the loss by po- of its spatial meanings (cf. 8a) as well as its role in perfectivizing diverse predicate types (cf. $8 \mathrm{~b}$ ) resulted in it performing a similar role, by contributing to a redefinition of the prototypical meaning of the pf aspect, i.e., of the semantic distinction between the pf and impf in verbs with other prefixes. Delimitative verbs are important in this respect, because their profile of a limited, indefinite duration of a predicate in time, i.e., $-\mathrm{S} \rightarrow \mathrm{S} \rightarrow-\mathrm{S}$, reveals the core meaning of po-: abstract limitation in time irrespective of telicity (completion), recall in this regard Shull's (163) view that po- perfectives are resultative or delimitative based primarily on the telicity or atelicity of the source verb. Thus, when $p o$ - combines with a predicate that is conceptualized as telic (e.g., stroit $^{{ }^{i}}$ ) it creates a resultative, whereas when it combines with a predicate conceptualized as atelic (e.g., stojat' 'stand') it creates a delimitative. As suggested above, this effect is much different from the TRANSITION FROM $S^{1}$ TO $S^{2}$ expressed by $s-/ z$ - (which is why the latter does not derive delimitatives in the western languages). Why exactly is this the case? Certainly the delimitative schema $-\mathrm{S} \rightarrow \mathrm{S} \rightarrow-\mathrm{S}$ is not incompatible with resultativity; rather, it is the inclusion of two temporally contiguous situations in the profile base that are not the profiled situation (S) that constitutes the important difference. I contend that these temporally contiguous situations are in fact the prior and subsequent states of affairs in the definition of temporal definiteness of the eastern pf given in section 1; thus, the schema $-\mathrm{S} \rightarrow \mathrm{S} \rightarrow-\mathrm{S}$ is in fact equivalent to $\mathrm{X} \rightarrow \mathrm{S} \rightarrow \mathrm{Y}$ (recall section 1, where temporal definiteness was schematized as $\mathrm{X} \rightarrow \mathrm{S} \rightarrow \mathrm{Y}$, where $\mathrm{S}$ is the situation profiled by the verb and $\mathrm{X}$ and $\mathrm{Y}$ represent the temporally contiguous, qualitatively different states of affairs). Thus, it was the profile of po- of a situation sequential in time to two contiguous, qualitatively different states of affairs $\mathrm{X}$ and $\mathrm{Y}$ that played an important role in the restructuring of the eastern pf aspect. If we assume that most other prefixes (Rus data will be taken as representative) profiled a (spatially-based) telicity, i.e., the TRANSITION FROM $S^{1}$ TO $S^{2}$, then we may say that the following analogy took

\footnotetext{
${ }^{60}$ Note that the eastern languages and Pol, all of which have productive delimitatives, also have pf determinate verbs of motion prefixed in po-. Blg has lost poiti ${ }^{p}$ 'go', but Middle Blg did have it (cf. Lilov 1964: 110-11); note that Blg still has other ingressive verbs of motion, e.g., pobjagna $^{p}$ 'run'. So there is a definite correlation between the development of delimitatives and the existence of determinate verbs of motion prefixed in $p o$ - in a given Slavic language.
} 
place: the relation napisat'p $^{p}$ : pisat ${ }^{i}$, i.e., a resultativity distinction based on the TRANSITION FROM $S^{1}$ TO $S^{2}$ is reanalyzed on the basis of the relation posidet ${ }^{p}$ : sidet $^{\prime i}$, a distinction based on $\mathrm{X} \rightarrow \mathrm{S} \rightarrow \mathrm{Y}$, with the result that the relation between the telic pair napisat'p : pisat ${ }^{\prime i}$ is now a distinction based on $\mathrm{X} \rightarrow \mathrm{S} \rightarrow \mathrm{Y}$. In other words, napisat'p went from being a pf verb profiling a writing event that produces some result to being a pf verb which profiles a writing event that produces a result and which is located between a preceding situation $\mathrm{X}$ and a subsequent situation $\mathrm{Y}$ (cf. the definition of temporal definiteness given in section 1). ${ }^{61}$ This analogy is in fact a second retextualization, parallel to the restructuring of the aspectual semantics of the western prefixes to $s-/ z$ - However, in the eastern languages the restructuring is more significant. And I propose that it was a restructuring of this kind of the prototypical meaning of the eastern pf that produced the changes in aspect usage mentioned above that are described by Dickey (2000: 282-7), which basically involve an increasing restriction of the pf to contexts of sequentiality.

Of course, this hypothesis is highly speculative (as will be any hypothesis of historical semantic development). However, it has the advantage of accounting for the nature of perfectivizing prefixation in the eastern languages which, like the western languages, have developed only one préverbe vide. Moreover, this hypothesis allows us to account for the differences between the eastern and western groups with the same descriptive and theoretical concepts. Further, the hypothesized development and effect of perfectivizing $p o$ - in the eastern languages fits in chronologically to produce the changes in eastern aspect that are known to have occurred in the last four hundred years. Finally, it might be added that a semantic restructuring of all the eastern perfectivizing prefixes on the model of the temporal profile hypothesized for po- can account for the fact that, as Shull (228-30) concludes, Rus perfectivizing prefixation is on the average relatively abstract compared to $\mathrm{Cz}$ prefixation.

\section{Conclusion}

This article has presented a description of the distribution and origin of the innovative hybrid prefix $s-/ z$ - in the Slavic languages. $S$-/Z- developed primarily in a group of western languages-Cz, Slk, Sor, Sln, Pol, Ukr and Blr (as well as Kajkavian dialects of Cro). It has been argued that $s$-/z-played an important role in shaping the meaning of the perfective aspect in a group of western languages $(\mathrm{Cz}, \mathrm{Slk}$, Sor, Sln), which have already been demonstrated to comprise a western aspectual type by Dickey (2000). The remaining Slavic languages did not develop $s-/ z-$. Cro and Srb have been argued to be languages that have not developed a préverbe vide, so that the aspectual systems of these two languages are still based on the mechanism of subsumption; nevertheless, the semantic difference between aspect in Cro/Srb and the western $s-/ z$ - languages is not great, and $\mathrm{Cro} / \mathrm{Srb}$ pattern closely to the languages of the western group as far as aspectual usage is concerned (cf., Dickey 2000). Rus,

\footnotetext{
${ }^{61}$ As in the case of $s-/ z$ - in the west, this is not meant as a claim that the rise of delimitatives was the sole cause of the change of the meaning of the eastern pf from totality to temporal definiteness. It is very probable that the eastern telic pf verbs were developing increased associations with temporal localization anyway, and that the process described here was a kind of final stage or reinforcement of that development. The lack of German language interference in the eastern languages is surely important in this respect, but as pointed out in fn. 51 , this issue cannot be dealt with here.
} 
Mac and Blg did not develop $s-/ z$ - either, but did develop another préverbe vide, perfectivizing po-. Po- also became highly productive in Ukr, Blr and Pol. East Slavic, Mac and Blg all share an eastern aspectual system (cf. Dickey 2000), and it has been argued here that the eastern system was semantically shaped to a great extent by perfectivizing $p o-$, regardless of whether $s-/ z$ - was also developed in an individual language (Ukr, Blr) or not (Rus, Mac, Blg). Pol was also significantly affected by the development of po-, but not to the degree of the eastern languages, so that aspectually it is a transitional zone that patterns fairly close to the eastern languages.

The approach taken here, that in the respective language groups either $s-/ z$ - or po- has come to be the dominant préverbe vide, is innovative in that unlike previous approaches it assumes that prefixation has played a more active role in the semantic formation of the pf aspect in Slavic aspect systems: $s-z$ - has played this role in the west, whereas $p o$ - has played it in the east. It has been suggested that the developments of $s-/ z$ - and $p o$ - in the respective language groups have been similar in many ways: they have both emerged as abstract perfectivizing prefixes, and have both become productive in the perfectivization of verbs of diverse predicate types, in addition to other minor similarities. The grammaticalization of $s-/ z-$ as a préverbe vide in the western languages contributed to the development of totality as the prototypical meaning of the $\mathrm{pf}$ aspect, whereas the grammaticalization of $p o-$ as a préverbe vide in the eastern languages contributed to the development of the prototypical meaning of the pf aspect from totality to temporal definiteness.

It has further been argued that these prefixes have participated in atypical grammaticalization processes involving their spread through different classes of verbs by means of a process called retextualization (cf. Nichols and Timberlake 1991), as well as the restructuring of the pf semantics of the other perfectivizing prefixes in the respective language groups. In this way, $s-z-$ and $p o$ - have each exerted a great influence on the meaning of the pf aspect in the respective language groups without having been completely generalized as markers of perfectivity. Though the hypotheses of their developments (especially in the case of the spread of perfectivizing/delimitative $p o$-) are admittedly speculative, they accord well with the facts as we know them concerning the east-west aspectual division, and have the advantage of correlating differences in aspect morphology with differences in usage between the western and eastern groups.

\section{References}

Agrell, Sigurd. (1908) Aspektänderung und Aktionsartbildung beim polnischen Zeitworte. Lund: Håkan Ohlssons Buchdruckerei.

Anan'eva, N. E. (2003) "Rol' dannyx glagol'nogo slovoobrazovanija v sovremennyx zapadnoslavjanskix dialektax dlja izučenija istoričeskix processov slavjanskoj glagol'noj derivacii”. A. M. Moldovan, ed. Slavjanskoe jazykoznanije. XIII Meždunarodnyj s"ezd slavistov. Ljubljana, 2003 g. Doklady rossijskoj delegacii. Moscow: Indrik, 7-18. 
Anstatt, Tanja. (2003a) "Die Quantelung des zweiten Arguments im Russischen: Der Typus s"est' jabloko - poest' supu”. Thomas Daiber, ed. Linguistische Beiträge zur Slavistik IX. Munich: Otto Sagner, 7-30.

- -. (2003b) "Das Verbalpräfix po- im Polnischen”. Zeitschrift für slavische Philologie 62: 359-385.

Avilova, N. S. (1964) "Razvitie pristavočnogo glagol’nogo slovoobrazovanija". V. V. Vinogradov and N. Ju. Švedova, eds. Očerki po istoričeskoj grammatike russkogo literaturnogo jazyka XIX veka. Glagol, narečie, predlogi $i$ sojuzy. Moscow: Izdatel'stvo "Nauka", 45-104.

Atraxovič (Krapiva) K. K. and M. B. Bulaxaw, eds. (1962) Hramatyka belaruskaj movy. Tom 1: Marfalohija. Minsk: Vydavectva Akadèmii navuk BSSR.

Bajec, Anton. (1959) Besedotvorje slovenskega jezika. IV: Predlogi in predpone. Ljubljana: Slovenska akademija znanosti in umetnosti.

Barentsen, Adrian. (1995) “Trexstupenčataja model' invarianta soveršennogo vida v russkom jazyke”. Stanisław Karolak, ed. Semantika $i$ struktura slavjanskogo vida I. Cracow: Wydawnictwo Naukowe WSP, 1-26.

Bermel, Neil. (1997) Context and the Lexicon in the Development of Russian Aspect. Berkeley: University of California Press.

BLDR 7 = D. S. Lixačev et al., eds. (2000) Biblioteka literatury drevnej Rusi. Tom 7. St. Petersburg: Nauka.

Bogdanova, V. A. (1963) “O pristavkax vy- i $i z-$ v slavjanskix jazykax". I. A. Vinnikova, ed. Voprosy slavjanskoj filologii. $K$ V Meždunarodnomu s"ezdu slavistov. Saratov: Izdatel'stvo Saratovskogo universiteta, 297-308.

Breu, Walter. (2000) "Der Verbalaspekt in der Obersorbischen Umgangssprache im Rahmen des ILA-Modells". Walter Breu, ed. Slavistische Linguistik 1999. Referate des XXV. Konstanzer Slavistischen Arbeitstreffens, Konstanz 7.-10. 9. 1999. Munich: Otto Sagner, 37-76.

Bulyko, Aleksandr Nikolaevič, et al. (1990) Sopostavitel'noe opisanie russkogo i belorusskogo jazykov. Morfologija. Minsk: Navuka i tèxnika.

Camus, Remi. (1998) "Quelque considérations sur le préverbe po- en russe contemporain". Revue des Études Slaves LXX(1): 101-112.

Čertkova, Marina. (1996) Grammatičeskaja kategorija vida v sovremennom russkom jazyke. Moscow: Izdatel'stvo Moskovskogo universiteta.

Cockiewicz, W. (1992) Aspekt na tle systemu stowotwórczego polskiego czasownika $i$ jego funkcyjne odpowiedniki w języku niemieckim. Kraków: Nakład Uniwersytetu Jagiełłonskiego.

Comrie, Bernard. (1976) Aspect. Cambridge: Cambridge University Press.

Dickey, Stephen M. (2000) Parameters of Slavic Aspect: A Cognitive Approach. Stanford: CSLI.

- -. (2001a) "The Temporalization of the Prefix po- in Slavic". Paper presented at the Second Annual Conference of the Slavic Cognitive Linguistics Association, University of Virginia, Charlottesville, VA. 
- -. (2001b) "Semelfactive -nQ- and the Western Aspect Gestalt". Journal of Slavic Linguistics 9(1): 25-48.

- -. (2003) "Verbal aspect in Slovene". Sprachtypologie und Universalienforschung.

Dickey, Stephen M. and Hutcheson, Julie. (2003) "Delimitative Verbs in Russian, Czech and Slavic". Robert A. Maguire and Alan Timberlake, eds. American contributions to the Thirteenth International Congress of Slavists. Columbus, Ohio: Slavica, 23-36.

Dmitrieva, Ol'ga. (2000) "Formirovanie sistemy russkix delimitativnyx glagolov". T. V. Kočetkova, ed. Predloženie i slovo: paradigmatičeskij, tekstovyj $i$ kommunikativnyj aspekty. Saratov: Izdatel'stvo Saratovskogo pedagogičeskogo instituta, 28-33.

Gebauer, Jan. (1963) Historická mluvnice jazyka českého. Díl I: Hláskosloví. Prague: Nakladatelství Československé akademie věd.

Greenberg, Marc L. (2000) A Historical Phonology of the Slovene Language. Heidelberg: Carl Winter Verlag.

Grickat, Irena. (1957) "O nekim vidskim osobenostima srpskohrvatskog glagola". Južnoslovenski filolog XXII: 65-128.

Guiraud-Weber, Marguerite. (1998) "La préfixation des emprunts verbaux en russe et en polonais". Revue des Études Slaves LXX/1: 67-77.

Hauser, Přemysl. (1995) "Slovesa se zdvojenými předponami zne-, zane- (zneklidnit, zanedbat)". Petr Karlík, Jana Pleskalová and Zdenka Rusínová, eds. Pocta Dušanu Šlosarovi. Sborník k 65. narozeninám. Boskovice: Nakladatelství Albert.

HEWONS $=(1978-89)$ Historisch-etymologisches Wörterbuch der ober- und niedersorbischen Sprache. Bautzen: Domowina-Verlag.

Hopper, Paul J. and Elizabeth Closs Traugott. (1993) Grammaticalization. Cambridge: Cambridge University Press.

Horecký, Ján. (1959) Slovotvorná sustava slovenčiny. Podstatné meno, prídavné meno, sloveso. Bratislava: Vydavatelstvo Slovenskej akadémie vied.

Hujer, Oldřich. (1922/1961) "Praslovanské v'bz-, jbz- v češtině”. In Př́spěvky k historii a dialektologii českého jazyka. Prague: Nakladatelství československé akademie věd, 116-125.

Ivančev, Svetomir. (1971) Problemi na aspektualnostta v slavjanskite ezici. Sofia: Błlgarska akademija na naukite.

Ivanova, Kalina. (1966) Desemantizicija na glagolnite predstavki v sbvremennija bъlgarski knižoven ezik. Sofia: Błlgarska akademija na naukite.

Janka, Wolfgang. (1997) "Zur Unterscheidung der tschechischen Verbalpräfixe s(e)und z(e)-". Anzeiger für slavische Philologie XXV: 101-11.

Jedvaj, Josip. (1956) "Bednjanski govor". Hrvatski dijalektološki zbornik 1: 279-330.

Kalsbeek, Janneke. (1998) The Čakavian Dialect of Orbanići near Žminj in Istria. Amsterdam: Rodopi.

Klemensiewicz, Z., T. Lehr-Spławiński and S. Urbańczyk. (1981) Gramatyka historyczna języka polskiego. Warsaw: Państwowe wydawnictwo naukowe. 
Kopečný, František. (1962) Slovesný vid v češtině. Prague: Nakladatelství Československé akademie věd.

Kucała, Marian. (1966) Rozwój iteratiwów dokonanych w języku polskim. Wrocław: Zakład Narodowy im. Ossolińskich.

Langacker, Ronald. (1987) Foundations of Cognitive Grammar: Volume 1. Stanford: Stanford University Press.

- -. (1988) “A Usage-Based Model”. B. Rudzka-Ostyn, ed. Topics in Cognitive Linguistics. Amsterdam: John Benjamins, 127-61.

Lehmann, Christian. (1995) Thoughts on Grammaticalization. Munich: Lincom Europa.

Lehmann, Volkmar. (1988) "Der russische Aspekt und die lexikalische Bedeutung des Verbs". Zeitschrift für slavische Philologie 48(1): 171-81.

- -. (1999) "Sprachliche Entwicklung als Expansion und Reduktion". Tanja Anstatt, ed. Entwicklungen in slavischen Sprachen. Munich: Otto Sagner, 160-254.

Marvan, Jiří. (2000) Jazykové milénium. Slovanská kontrakce a její český zdroj. Prague: Academia.

Maslov, Jurij S. (1961) “Rol' tak nazyvaemoj perfektivacii i imperfektivacii v processe vozniknovenija slavjanskogo glagol'nogo vida”. V. V. Vinogradov, ed. Issledovanija po slavjanskomu jazykoznaniju. Moscow, 165-95.

Mende, Julia. (1999) "Die Grammatikalisierung des russischen Aspekts". Tanja Anstatt, ed. Entwicklungen in slavischen Sprachen. Munich: Otto Sagner, 285-325.

Merše, Majda (1995) Vid in vrstnost glagola v slovenskem knjižnem jeziku 16. stoletja. Ljubljana: Slovenska akademija znanosti in umetnosti.

MSJ = Ružička, Jozef, ed. (1966) Morfológia slovenského jazyka. Bratislava: Vydavatel'stvo Slovenskej akadémie vied.

Nefed'ev, M. V. (1994) “Semantičeskaja èvoljucija glagol’nyx pristavok $n a-$ i $o b$ - v istorii russkogo jazyka XI-XVIII vv.”. Voprosy jazykoznanija 4: 73-83.

Nichols, Johanna and Alan Timberlake. (1991) "Grammaticalization as Retextualization". Elizabeth Cross Traugott and Bernd Heine, eds. Approaches to Grammaticalization 1: Focus on Theoretical and Methodological Issues. Amsterdam: John Benjamins, 129-46.

Nørgård-Sørensen, Jens. (1997) “Tense, Aspect and Verbal Derivation in the Language of the Novgorod Birch Bark Letters”. Russian Linguistics 21: 1-21.

Nübler, Norbert. (1990) "Zum Begriff der Subsumptionspräfixe in der Aspektforschung”. Anzeiger für slavische Philologie XX: 123-34.

OSSJ = Odzadnji slovar slovenskega jezika. Ljubljana: Slovenska akademija znanosti in umetnosti. (CD-Rom version.)

Peco, Asim. (1991) Pregled srpskohrvatskih dijalekata. Belgrade: Naučna knjiga.

Piernikarski, Cezar. (1975) Czasowniki z prefiksem po- w języku polskim i czeskim na tle rodzajów akcji w językach stowiańskich. Warsaw: Państwowe wydawnictwo naukowe.

Plotnikova, Ol'ga. (1971) "Dvuvidovye glagoly inostrannogo proisxoždenija v slovenskom literaturnom jazyke”. Vestnik Moskovskogo universiteta 1: 28-36. 
Poldauf, Ivan. (1954) "Spojování s předponami při tvoření dokonavých sloves v češtině”. Slovo a slovesnost XV/2: 49-65.

Rusanivs'kyj, V. M. (1978) “Dieslovo”. V. V. Nimčuk, ed. Istorija ukrajins’koji movy. Morfologija. Kiev: Naukova dumka, 235-341.

Rusínová, Zdenka. (2001) "Slovesné neologismy a problém vidu”. Mieczysław Balowski and Jiří Svoboda, eds. Język i literatura czeska u schytku XX wieku. Wałbrzych/Ostrava: 219-225.

Saloni, Z. (2001) Czasownik polski. Odmiana. Stownik. Warsaw: Wiedza Powszechna.

Seliščev, L. M. (1941/1969) Slavjanskoe jazykoznanie 1: Zapadnoslavjanskie jazyki. Moscow: Narkomprosa. (C. H. van Schooneveld, ed. Slavistic Printings and Reprintings 106. The Hague: Mouton.)

Šerex, Jurij. (1951) Narys sučasnoji ukrajins'koji literaturnoji movy. Munich: Molode žyttja.

Shull, Sarah. (2003) The Experience of Space: The Privileged Role of Spatial Prefixation in Czech and Russian. Munich: Otto Sagner.

Sigalov, P. S. (1975) "Istorija russkix ograničitel'nyx glagolov”. Trudy po russkoj $i$ slavjanskoj filologii: Serija lingvističeskaja 23: 141-81.

Słoński, Stanisław. (1937) Funkcje prefiksów werbalnych w języku starostowiańskim (starobułgarskim). Warsaw: Nakład Towarzystwa Naukowego Warszawskiego.

Šlosar, Dušan. (1981) Slovotvorný vývoj českého slovesa. Brno: Univerzita J. E. Purkyně.

Śmiech, Witold. (1986) Derywacja prefiksalna czasowników polskich. Zakład Narodowy im. Ossolińskich.

Smirnov, L. N. (1970) Glagol'noe vidoobrazovanie v sovremennom slovackom jazyke. Moscow: Nauka.

SSJČ = (1989) Slovník spisovného jazyka českého. Prague: Nakladatelství československé akademie věd.

SSKJ = (1970-91) Slovar slovenskega knjižnega jezika. Ljubljana: Slovenska akademija znanosti in umetnosti. (CD-Rom version.)

$S S M=(1977)$ Slovnyk staroukrajins'koji movy XIV-XV st. Kiev: Naukova dumka.

Staroslavjanskij slovar' = R. M. Cejtlin, R. Večerka, E. Blagovoj, eds. (1994) Staroslavjanskij slovar' (po rukopisjam X-XI vekov). Moscow: Russkij jazyk.

Štyreva, E. D. (1992) “K voprosu o vzaimodejstvii kategorii vida s glagol'noj leksikoj”. L. N. Smirnov, ed. Issledovanija po slovackomu jazyku. Moscow: Rossijskaja akademija nauk, 166-78.

Szelesiński, Iwo. (1972) "Wyrazy z przedrostkiem wz- (ws-, wez-, wes-) w polszczyźnie”. Rozprawy komisji językowej XVIII: 211-29.

Tixonov, A. N. (1998) "Vidovye korrelacii v sovremennom russkom jazyke". Marina Ju. Čertkova, ed. Tipologija vida: Problemy, poiski, rešenija. Moscow: 466-77.

Toops, Gary H. (2001) "Aspectual Competition and Iterative Contexts in Contemporary Upper Sorbian”. Journal of Slavic Linguistics 9(1): 127-54. 
Trávníček, František. (1923) Studie o českém vidu slovesném. Prague: Náklad České akademie věd a umění.

Ugrinova-Skalovska, Rada. (1960) Značenjata na glagolskite prefiksi vo makedonskiot jazik. Skopje: Institut za makedonski jazik.

Vintr, Josef. (2001) Das Tschechische. Hauptzüge seiner Sprachstruktur in Gegenwart und Geschichte. Munich: Otto Sagner.

Voloxina, G. A., and Z. D. Popova. (1997) "Kategorija glagol'nogo vida v svete semantičeskogo ustrojstva glagol’nyx pristavok”. Marina Ju. Certkova, ed. Trudy aspektologičeskogo seminara Filologičeskogo fakulteta MGU im. M. V. Lomonosova 3. Moscow: 34-41.

Werner, Eduard. (2003) Die Verbalaffigierung im Obersorbischen. Bautzen: Domowina-Verlag.

Witkowska-Gutkowska, Maria. (1999) Staropolskie prefiksalne dublety czasownikowe i ich wspótczesne odpowiedniki. Łódź: Wydawnictwo Uniwersytetu łódzskiego.

Xlebnikova-Prokopovič, E. N. (1956) “Glagol'noe formoobrazovanie pri pomošči pristavok v pamjatnikax russkoj pis'mennosti vtoroj poloviny XVII veka”. Doklady $i$ soobščenija Instituta jazykoznanija 10: 130-55.

Zel'dovič, Gennadij. (2002) Russkij vid: Semantika i pragmatika. Toruń: Uniwersytet Mikołaja Kopernika.

Prispelo decembra 2004, sprejeto februarja 2005

Received December 2004, accepted February 2005

\section{$S$-/Z- in gramatikalizacija glagolskega vida v slovanščini}

Prispevek obravnava nastanek predpone $s-/ z$ - kot posledico sovpada predpon $*_{s b-}$ in $* j b z-$ po izgubi polglasnikov. Ceprav se je enotna predpona razvila v $s-/ z-\mathrm{v}$ češčini, slovaščini, lužiščini, slovenščini, ukrajinščini in beloruščini, pa je imela največ posledic za glagolski vid v češčini, slovaščini, lužiščini in slovenščini, kjer je predpona postala najbolj produktivna (izključno) kot préverbe vide. Drugi slovanski jeziki izkazujejo drugačne sisteme predponske dovršnosti. V hrvaščini in srbščini se ohranja arhaičen sistem, v katerem se leksikalno enakovredni dovršni glagoli tvorijo iz nedovršnih z različnimi predponami. $\mathrm{V}$ poljščini se je razvila druga vrsta préverbe vide, namreč s predponama $p o$ - poleg inovativne $s$-/z-, enako tudi v ukrajinščini in beloruščini. $\mathrm{V}$ preostalih slovanskih jezikih (ruščina, bolgarščina, makedonščina) se je kot préverbe vide razvila predpona po- (tu ni prišlo do sovpada *sb- in *jbz-). Vseslovanska slika o predponah $s-/ z$ - in $p o-\mathrm{v}$ pretežni meri ustreza Dickeyjevi (2000) razvrstitvi slovanskih jezikov v dve skupini glede na glagolski vid: vzhodno (ruščina, ukrajinščina, beloruščina in bolgarščina) in zahodno (češčina, slovaščina, lužiščina in slovenščina) $\mathrm{z}$ dvema prehodnima conama (poljščina in hrvaščina ter srbščina). Avtor zagovarja stališče, da se je predpona $s$-/z-gramatikalizirala kot préverbe vide, pri čemer je $\mathrm{v}$ leksikalnih vrstah, $\mathrm{v}$ katerih $s$-/z-nastopa kot préverbe vide, prišlo do delitve $\mathrm{s}$ preubeseditvijo (retextualization). Ta postopek je pripomogel $\mathrm{k}$ ustalitvi celostnosti (totality) kot osnovnega pomena zahodnega dovršnega vida, iz 
katerega izvira sodobni zahodni sistem vidske rabe. Vzporedni postopek s predpono po- v vzhodnih jezikih naj bi igral pomembno vlogo pri razvoju pomena vzhodnega dovršnika v kategorijo časovne določnosti (temporal definiteness) in ustvaril sodobni sistem vidske rabe $\mathrm{v}$ teh jezikih.

\section{$S$-/Z- and the Grammaticalization of Aspect in Slavic}

This paper examines the rise of $s$ - $/ z$ - as a coalescence of in the prefixes $* s b$ and $* j b z$ - resulting from jer-fall. Though $s-/ z$ - was developed in Czech, Slovak, Sorbian, Slovene, Polish, Ukrainian and Belarusian, it has had the most consequences for aspect in Czech, Slovak, Sorbian and Slovene, where this prefix has arguably been most productive (and exclusively so) as a préverbe vide. The other Slavic languages have developed different systems of perfectivizing prefixation. Croatian and Serbian are argued to represent an archaic system of subsumption, relying largely on the semantic overlap of various prefixes with imperfective source verbs to create lexically identical perfective partner verbs. Polish has developed another préverbe vide, $p o-$, alongside innovative $s-/ z-$, as have Ukrainian and Belarusian. The remaining Slavic languages, Russian, Bulgarian and Macedonian developed po- as a préverbe vide (and never merged $*^{*} s$ - and $* j b z$ ). The cross-Slavic picture regarding $s-/ z$ - and po- corresponds in large part to Dickey's (2000) division of Slavic into two aspectual groups, an eastern group (Russian, Ukrainian, Belarusian and Bulgarian) and a western group (Czech, Slovak, Sorbian and Slovene), as well as two transitional zones (Polish and Croatian/Serbian). It is argued that $s$-/z- underwent a grammaticalization process whereby the lexical classes of verbs for which it functions as a préverbe vide were diversified by a process of retextualizaton, which helped to stabilize totality as the meaning of the western perfective, producing the current western pattern of usage. A parallel process involving po- in the eastern languages is hypothesized to have played an important role in the development of the meaning of the eastern perfective to a category called temporal definiteness, which has produced the current eastern pattern of aspect usage. 